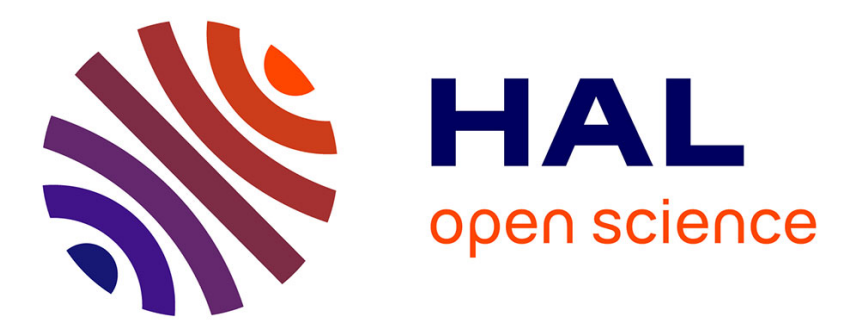

\title{
Morphometric interpretation of the northwest and southeast slopes of Tenerife, Canary Islands
}

C. Palomo, J. Acosta, J. L. Sanz, P. Herranz, A. Mufioz, E. Uchupi, J. Escartin

\section{- To cite this version:}

C. Palomo, J. Acosta, J. L. Sanz, P. Herranz, A. Mufioz, et al.. Morphometric interpretation of the northwest and southeast slopes of Tenerife, Canary Islands. Journal of Geophysical Research: Solid Earth, 1997, 102 (B9), pp.20325-20342. 10.1029/97JB01281 . hal-02324137

\section{HAL Id: hal-02324137 \\ https://hal.science/hal-02324137}

Submitted on 21 Oct 2019

HAL is a multi-disciplinary open access archive for the deposit and dissemination of scientific research documents, whether they are published or not. The documents may come from teaching and research institutions in France or abroad, or from public or private research centers.
L'archive ouverte pluridisciplinaire HAL, est destinée au dépôt et à la diffusion de documents scientifiques de niveau recherche, publiés ou non, émanant des établissements d'enseignement et de recherche français ou étrangers, des laboratoires publics ou privés. 


\title{
Morphometric interpretation of the northwest and southeast slopes of Tenerife, Canary Islands
}

\author{
Teide Group ${ }^{1}$
}

\begin{abstract}
Both the northwest and southeast slopes of Tenerife, Canary Islands, owe their morphology to catastrophic sediment failures. An area of $4100 \mathrm{~km}^{2}$ and a volume of about $2362 \mathrm{~km}^{3}$ were involved in the failure. A 100- to 600-m-high scarp on the upper slope separates the sediment failures in the Orotova and Icod de los Vinos Valleys on the northwest coast from those on the slope. A similar (700 m high) scarp also separates the failures on the southeast slope from the failure in Güimar Valley on land. The sediment failure off I as Bandas Del Sur volcanic fan does not have any land counterparts and was the result of the failure of the front (1700 m high) of this depocenter; two generations of debris flows are mappable off this depocenter. We infer that the slopes off Orotova, Icod, and Güimar represent the front of the debris avalanche and/or creep deposits that were created during the formation of the valleys. Downslope from the debris avalanche fronts are irregular surfaced masses extending to the base of the slope. The front may define the contact between the more dense deposits onshore and upper slope and the more fluid deposits on the lower slope. Incised on the debris avalanche on the northwest lower slope are three channeled debris flows grading seaward into turbidites. Only one of these channels occurs on the southeast slope. The breakaway surface of these sediment failures was the front of the debris avalanches and/or creep. We ascribe the failure of this front mainly to its rapid buildup, although groundwater sapping also may have contributed to its failure. On the southeast slope, movement along the northeast trending fault between Gran Canaria and Tenerife also may have been a contributing factor to the failure of the front. The debris flow deposits triggered by the failure of the sediment front on the northwest slope are characterized by ridges formed either by pressure between flows moving at different velocities or by scouring; at least one volcanic edifice occurs within the deposit. Although the avalanche and associated debris flow surfaces on the northwest slope appear pristine, being only partially covered by lava flow from a volcano in one of the channels, those on the southeast slope are partially buried by postfailure volcanics and detrital sediments. At the distal end of the slope failure masses, there are extensive fans. On the southeast slope these depocenters were reworked into a sediment drift field of northeast trending ridges by the southerly flowing North Atlantic Deep Water. On the surfaces of the fans off the northwest slope, there are exotic blocks transported downslope from their original positions either by riding on the surface of the highly dense debris avalanche or by being transported within the avalanche itself.
\end{abstract}

\section{Introduction}

Tenerife, the largest and highest of the Canary Islands off Africa, has a pyramid shape whose triangular base trends northeastward and whose apex is formed by a double-peak stratovolcano with Pico Viejo rising $3100 \mathrm{~m}$ and Teide rising $3718 \mathrm{~m}$ above sea level (Figure 1) [Bravo, 1962]. Volcanic construction of the island since the Miocene, 11.6 Ma, was along three radiating structural trends [Ancochea et al., 1990); Luongo et al., 1991; Carracedo, 1994]. Superimposed on the island's voluanic terrain are the south draining Güimar Valley and the north draining Orotova and Icod de los Vinos Valleys.

\footnotetext{
${ }^{1}$ C. Palomo, J. Acosta, J. L. Sanz, P. Herranz, and A. Muñoz, Instituto Español de Oceanografia; E. Uchupi, Woods Hole Oceanographic Institution; J. Escartin, WHOI/MIT Joint Program in Occanography/Applied Ocean Science and Engineering (now at Department of Geological Sciences, University of Durham).

Copyright 1997 by the American Geophysical Union.

Paper number 97JB01281.

0148-0227/97/97JB-01281\$09.00
}

The valleys are box-shaped rather than V-shaped in cross section and have 7 - to 10 -km-wide flat floors and amphitheatershaped heads. Their sidewalls are several hundred meters high and rectilinear, with some segments being nearly vertical. Güimar and Orotova are partially and Icod is nearly filled with lavas that are younger than those that crop out along their walls. Subsurface horizontal galleries indicate that the valleys' sidewalls are not fault scarps and that a breccia is beneath the latest Pleistocene and Holocene lava fill in Orotava and Icod [Bravo, 1962]. Bravo [1962] estimated that the average thickness of the breccia is more than $350 \mathrm{~m}$. For our volume calculations (see below) we have assumed an average thickness of $0.5 \mathrm{~km}$ for the breccia and the chaotic volcanic deposits in Güimar Valley described bclow. In Güimar Valley the breccia is missing, and its stratigraphic position is occupied by a series of agglomerates of unknown thickness, a chaotic assemblage of volcanic material which texturally closely resembles the breccia [Coello, 1973]. 'The chaotic breccia in the Orotova Valley is partially exposed along the coast and on the east side of the Tigaiga massif [Bellido et al., 1988]. In places the breccia is 


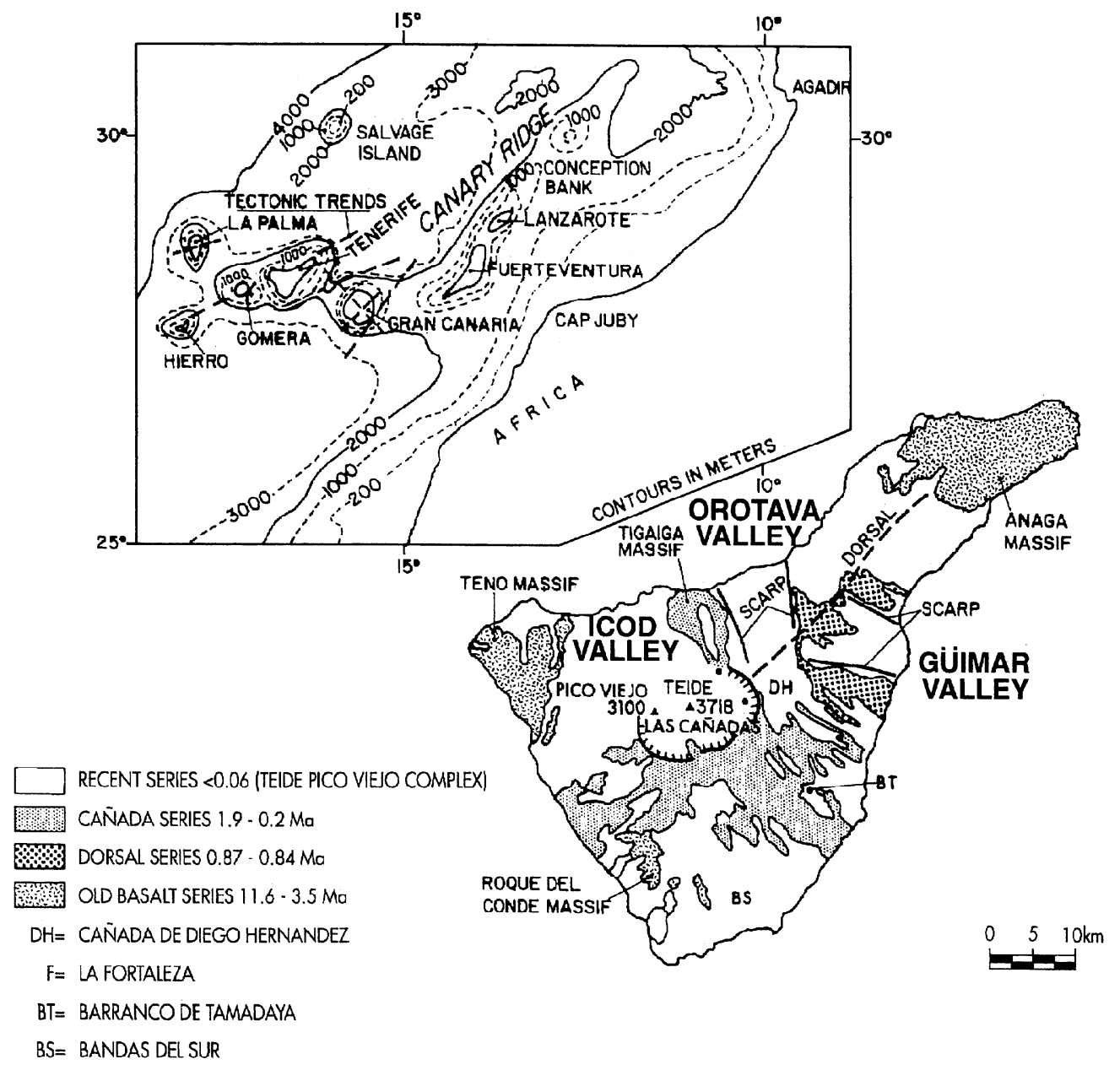

Figure 1. Bathymetric map of Canary Ridge showing locations of islands and tectonic trends in the region and geologic map of Tenerife. Tectonic trends are from Bosshard and MacFarlane [1970, Figure 16] and the geologic map is modified from Ancochea et al. [1990, Figure 1]. BS, Las Bandas del Sur; DH, Cañada Diego IIernandez; BT, Barranco de Taganana.

exposed along the sea cliff; in others it is dammed on the cliff by a block of Cañadas volcanics. In another locality the breccia along the sea cliff is fronted by a marine stack eroded out of the Cañadas volcanics forming one of the island of the Los Roques group at $16^{\circ} 34.3^{\prime} \mathrm{W}, 28^{\circ} 26^{\prime} \mathrm{N}$. At one of the sea cliff outcrops the breccia displays evidence of reworking by marine processes, a reworking that took place before the emplacement of the lava flows resting on the breccia.

Some volcanologists have proposed that the valleys, and the breccia associated with them, are the products of slope failures and subsequent mass movements created by the external collapse of the stratovolcanoes on the Cordillera Dorsal [Bravo, 1962; Navarro Latorre and Coello, 1989a, b], other volcanologists have proposed a combination of the episodic internal collapse of magma chamber and sector external collapse of the wall of the caldera [Booth, 1973; Marti et al., 1994, 1995], and still other volcanologists have proposed cumulative stresses produced by the growth of the volcanoes themselves [Carrecedo, 1994]. Only Palacios [1994] has suggested that the valleys in Tenerife were created by fluvial erosion. The shape of the valleys and their breccia fill, however, are incompatible with such an origin. J. M. Navarro Latorre (personal communication, 1996) proposed that the south draining Güimar Valley was formed 0.7 to $0.6 \mathrm{Ma}$, the north draining Orotova Valley cutting the head of Güimar Valley was formed 0.4 to (0.3 Ma, and the Las Cañadas caldera and Icod de los Vinos Valley north of the caldera was formed about 0.15 Ma. Watts and Masson [1995] have further inferred that the morphology of the northwest slope of the island is also the creation of mass wasting. Although their bathymetric and GLORIA data terminate at a depth of 100-600 m, Watts and Masson [1995] proposed that the onshore and offshore features are topographically continuous and are creations of the same mass movements. Failure on land probably was in the form of a rockfall (i.e., debris avalanche, rock avalanche) and/or creep (extremely slow moving avalanche) (elastic flows made of internally rigid blocks which roll, slide, or glide along shear planes), whereas the failure on the slope was in the form of avalanches and/or creep, slumping (an elastic-plastic flow of an undeformed rotational slide), debris flow (a plastic flow where shear is distributed throughout the flow), and turbidity currents (a viscous fluidal flow where the liquid of the mass has been exceeded) (see Varnes [1958], Dott [1963], Nardin et al. [1979], and Lee et al. [1993] for definition of terms).

Associated with the rockfall and/or creep in the Orotova and Icod Valleys are several gravity-driven glide blocks: the $10 \mathrm{~km}$ long, $5 \mathrm{~km}$ wide, and $1 \mathrm{~km}$ high Tigaiga massif and a block in the subsurface of Icod de Los Vinos [Coello, 1973, Figure 4]. 
The northerly transport of the Tigaiga massif and the other blocks by gravity gliding may have been the result of the high excess pore water pressure in the debris avalanche and/or creep breccia filling the valley. Such pressure, if present, would have acted as a lubricant for the slabs in the manner described by Bugge et al. [1988] for the Storegga slide. The transport of the block came to a halt when the cxcess pore water lubricant was drastically reduced. That the Tigaiga massif may be an exotic block is not unrealistic as Tuscaloosa Seamount in the Nuuanu debris avalanche off the Hawaiian Islands is $30 \mathrm{~km}$ long, $17 \mathrm{~km}$ wide, and $1.8 \mathrm{~km}$ high [Normark et al., 1993]. As the large slabs becamc anchorcd at their present positions at the mouth of the Orotava Valley, the rest of the debris avalanche and/or creep flowed around and over the blocks. Partial damming by the blocks also explains why the breccia south of the blocks is unusually thick at some sites.

\section{Present Investigation}

The present investigation of the Tenerife offshore area, cruise Teide 95, is part of the European Union "European Laboratory Volcanocs" Program which includes studies not only of Teide but of Santorini in Greece, Krafla in Iceland, Furnas in the Azores, Piton de la Fournaise in Reunion Island, Indian Ocean, and Etna in Italy (Second Workshop on European Laboratory Volcanoes, 1996). The prime objective of the Tcide phase of the program is to reconstruct the eruptive process of Teide Volcano. The present phase, one of eight studies (other studies include the gravity of Teide, magnetics of Teide, seismic monitoring of Teide, Tenerife's central volcanic complex, geodetic network of the caldera of Teide, geodesy and gravity of the Teide caldera, the Teide magmatic system, and a compilation of a geologic-geophysical database on Teide) of the volcano, concerns itself with the mapping of the morphology of the offshore area to determine, if possible, the volume of the pyroclastics offshore and to extend the survey as close as possible to the coast so as to define the relationships between the offshore slope morphology and the Orotova, Icod, and Güimar collapse valleys onshore. This investigation of the Tenerife offshore area also is part of an ongoing investigation by the Instituto Español de Oceanografia of the economic exclusive zone of Spain within the "Estudio HidrograficoOceanográfico de la Zona Económica Exclusiva Española." In future cruises we plan a systematic investigation of the rest of the archipelago which will be integrated with studies on land. The Tenerife cruise was originally planned for 1993 but had to be delayed until 1995 because of ship scheduling problems. On learning of the Watts and Masson [1995] study, the region of investigation of the northwest slope was expanded to include the upper insular slope and shelf and the distal parts of the slope failure deposits on the northwest slope, areas not adequately covered by Watts and Masson.

The swath bathymetric data recorded during the present investigation were obtained with a SIMRAD EM-12 System, similar to that used by Watts and Masson [1995], capable of resolving depths of a few meters. These data were logged using SIMRAD's Mermaid and Merlin software and subsequently processed using Neptune and Irap software. Slope maps of Tenerife were derived from multibeam maps gridded at 100 by $100 \mathrm{~m}$ using Neptune and Irap software, single-beam maps from the Instituto Hidrografîco de la Armada digitized and gridded with Irap and a digital topographic model (DTM) of Tenerife from the Instituto Geográfico Nacional. All these data were then integrated using Geographical Information System IberGis software to creatc a digital terrain model of Tenerife and the offshore area. Additional information on the morphology of the insular slopes was obtained from manually mounted mosaics of the backscatter amplitude data obtained with the EM-12 system.

Two different sound sources were used to record the shallow structure of both slopes, a $8000 \mathrm{~J}$ sparker and an air gun with volumes ranging from 55 to 535 cubic inches. The signals detected by an eight-channel SIG streamer were recorded digitally and processed in real time with an DELPH-2 system from Elics. Additional information on the shallow structurc was provided by a detailed seismic reflection survey made in 1979 by the Instituto Español de Oceanografia of the southern insular shelf using a Uni-Boom system. The geomagnetic field was recorded using a Geometrics G-876 marine magnetometer. Diurnal variations corrections were made with the aid of a GEOMAG magnetometer from the Instituto Geográfico Nacional Güimar Observatory. Gravity data were acquired with a Bell Aerospace-Textron (BGM-3) which was calibrated with the station at Cabildo Insular in Santa Cruz, Tenerife, using a Worden "Prospector" portable gravity meter. Results of this part of the investigation will be reported elsewhere. Global Positioning System (GPS) navigation during the cruise was by means of a double GPSD (two trimble receivers with two differential corrections, SKYFIX-Inmarsat and land-based differential stations) with an accuracy of $\pm 3 \mathrm{~m}$.

\section{Coastal-Offshore Region}

\subsection{Morphology of Northwest Coast and Insular Margin}

The northwest coast of Tenerife is dominated by the Anaga massif on the northeast and the Teno massif on the southwest forming two bastions extending northward beyond the general coast (Figure 1). The coastal region between the two massifs is in the form of a broad reentrant slightly convex to the north divided in two by the north trending Tigaiga massif. Orotova Valley is east of the Tigaiga massif and Icod de los Vinos Valley is west of it, located north of the Las Cañadas caldera. On their seaward sides the valleys are truncated by a northward facing, irregularly outlined, 50 - to 100 -m-high sea cliff [Bravo, 1952]. The occurrence of intertidal fossils about $8 \mathrm{~m}$ above sea level indicates that part of the relief of the sea cliff is the result of recent uplift. [Bravo, 1952]. The more recent lava flows, which originated from edifices on the upper valley and near the coast, have flowed down the length of the valley. In places, their emplacement has forced the shoreline northward a distance of $500 \mathrm{~m}$ [Bravo, 1952].

The seaward extension of the Anaga massif (A, Figure 3b) east of $16^{\circ} 30^{\prime} \mathrm{W}$ forms a broad arc convex northwestward that can be recognized to a depth of nearly $2400 \mathrm{~m}$ (Figures 2-3). At depths of less than $800 \mathrm{~m}$ this extension has a declivity of $16^{\circ}$, and beyond that depth it decreases to $11^{\circ}$. Superimposed on its surface is a poorly defined drainage system displaying a rough radial pattern draining toward the northwest and recognizable to a depth of at least $2400 \mathrm{~m}$ ( $\mathrm{H}$, Figure $3 \mathrm{~b})$. The presence of northwest trending elliptical shaped highs having reliefs of $150-300 \mathrm{~m}$ adds to the topographic grain of the Anaga massif seaward extension. At the base of the massif, and extending to a depth about $3300 \mathrm{~m}$, is a broad north trending swell whose east flank is dissected by two lows. The submarine segment of the Teno massif (F, Figure $3 b$ ) surveyed during the 


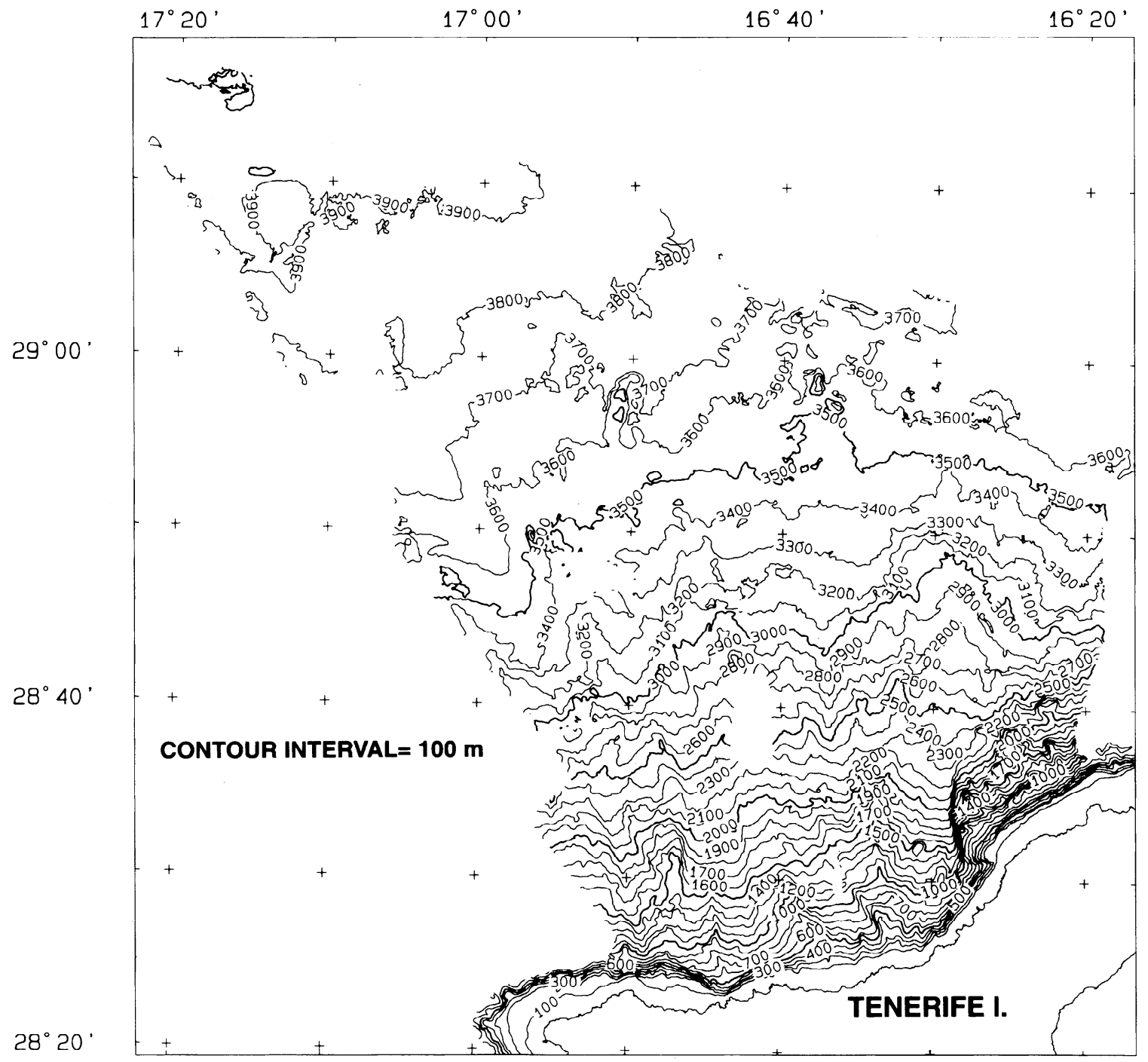

Figure 2. Simplified bathymetric chart (in meters) of the northwest slope of Tenerife compiled from swath data.

present investigation displays a more subdued morphology than the Anaga massif.

North of the Orotova and Icod Valleys and Tigaiga massif, between the Anaga and Teno massifs, is a relatively smooth 1to 2-km-wide erosional submarine rocky platform (Figure 3a) blanketed by patches of volcanic debris and bioclastic sand. Beyond the insular shelf is a 100 - to $600-\mathrm{m}$-high slope with a gradient from $4^{\circ}$ to as much as $16^{\circ}$ incised by box- and Vshaped canyons (X, Figure $3 \mathrm{~b}$ ). The rest of the insular slope off Anaga and Icod de los Vinos Valleys and Tigaiga massif has a more subdued topography than that off Anaga and Teno massifs. This subdued terrain consists of a north-northwest to north-northeast valley-ridge terrain extending from 100-600 $\mathrm{m}$ to a depth of 3100-3500 $\mathrm{m}$ (Figure 3a). The gradient of this valley-ridge terrain ranges from $6^{\circ}$ at depths of less than $1600 \mathrm{~m}$ to $4^{\circ}$ from 1600 to $2400 \mathrm{~m}$ to $2^{\circ}$ at a depth of about $3500 \mathrm{~m}$. Fronting both the valley-ridge province and the undulating terrains at the base of the Anaga and Teno massifs is an irregular surfaced apron with a gradient of $1^{\circ}$ to nearly $2^{\circ}$ extending to a depth of $4000 \mathrm{~m}$. The front of the apron has a gradient of $4^{\circ}-5^{\circ}$ and is roughly convex toward the north with its curvature being disrupted by north-south trending indentations. North of the apron is a northwesterly dipping low along whose axis is a system of poorly developed channels draining to the northwest (Figure 2). North of this low is a slope with a relief of about $75 \mathrm{~m}$ and depths of $3450 \mathrm{~m}$ along its crest.

The slope map illustrates the irregular morphology of the lower slope, a roughness due to the presence of numerous small highs which speckle the terrain, highs which became bigger downslope (Figure 3a). Additional topographic irregularities on the lower slope are the result of flat-bottomed boxshaped channels incised onto the rough terrain. These channel are $5-6 \mathrm{~km}$ wide and have side slopes up to $500 \mathrm{~m}$ high. Some of these marginal slopes are rectilinear and have a gradient ranging from $6^{\circ}$ to $17^{\circ}$; their morphologies are miniature versions of the valleys on land. As a result of the erosion of the valleys, the lower slope has been segmented into three topographic highs whose long axes are oriented downslope. The easternmost of these highs is located north of the Orotova Valley, the second one is located off the eastern end of the Cañadas Caldera, and a third one is located off the western side of Icod de los Vinos Valley next to the Teno massif. 


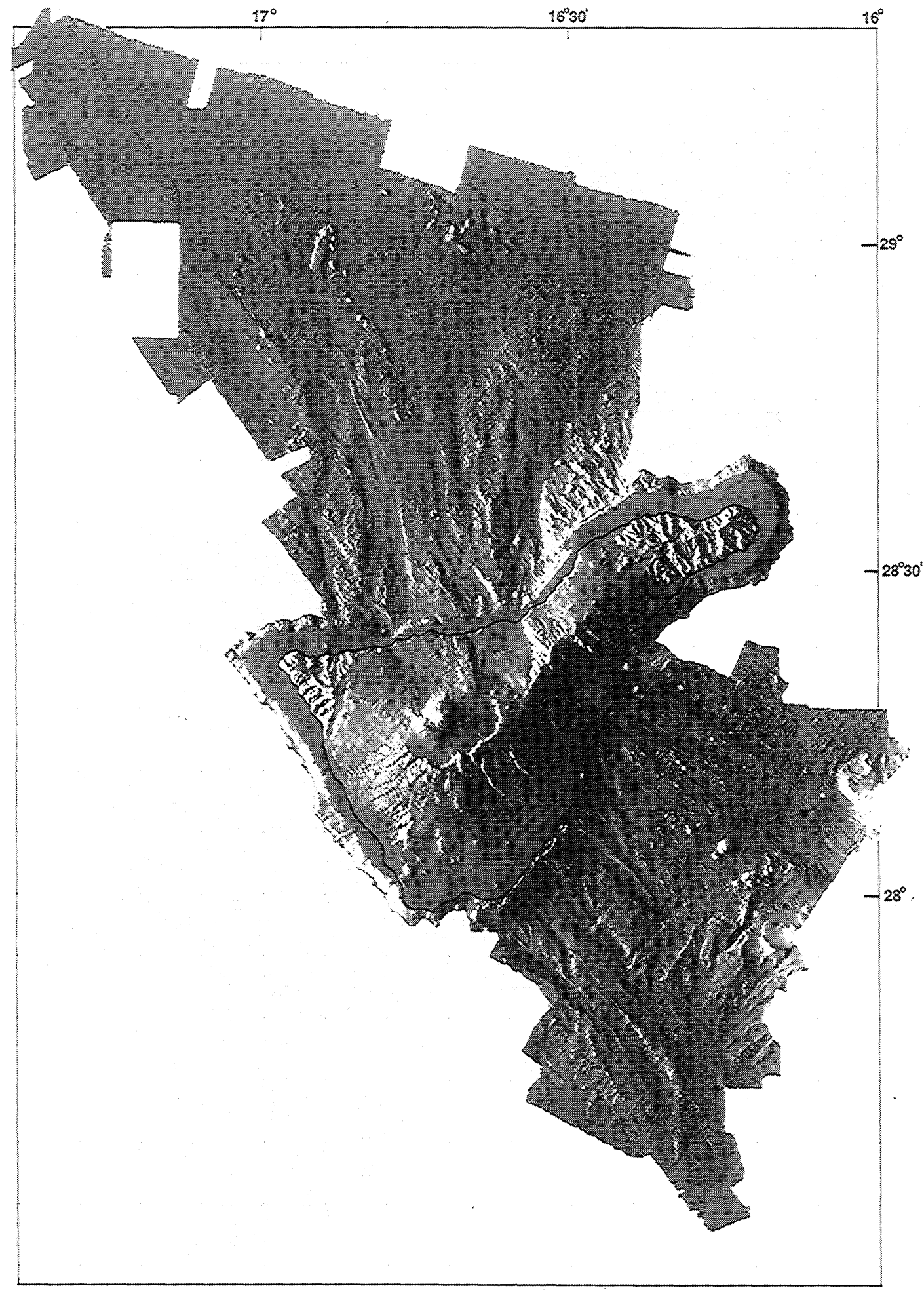

Figure 3a. Computer-gencrated slope map of the insular slopes of Tenerife from the swath bathymetric data, unpublished charts of the Instituto hidrográfico de la Armada, and land topographic data from the Instituto Geográfico Nacional.

Whereas the high off the Orotova Valley can be traced to the base of the lower slope, those off the eastern end of Cañadas caldera and the western edge of Icod Valley end abruptly downslope. At the northern end of the high off Las Cañadas caldera and the one off the western side of Icod Valley, next to Teno massif, is a chain of topographic highs (E, Figure $3 \mathrm{~b}$ ). A seismic reflection profile between the Anaga and Teno massifs (profile T-67, Figure 4) demonstrates the surface roughness of the region and provides a measure of its acoustic impcdancc. Little or no penetration is displayed by this recording as it crosses the hummocky topography.

The head of the valley next to Anaga massif is compound, 


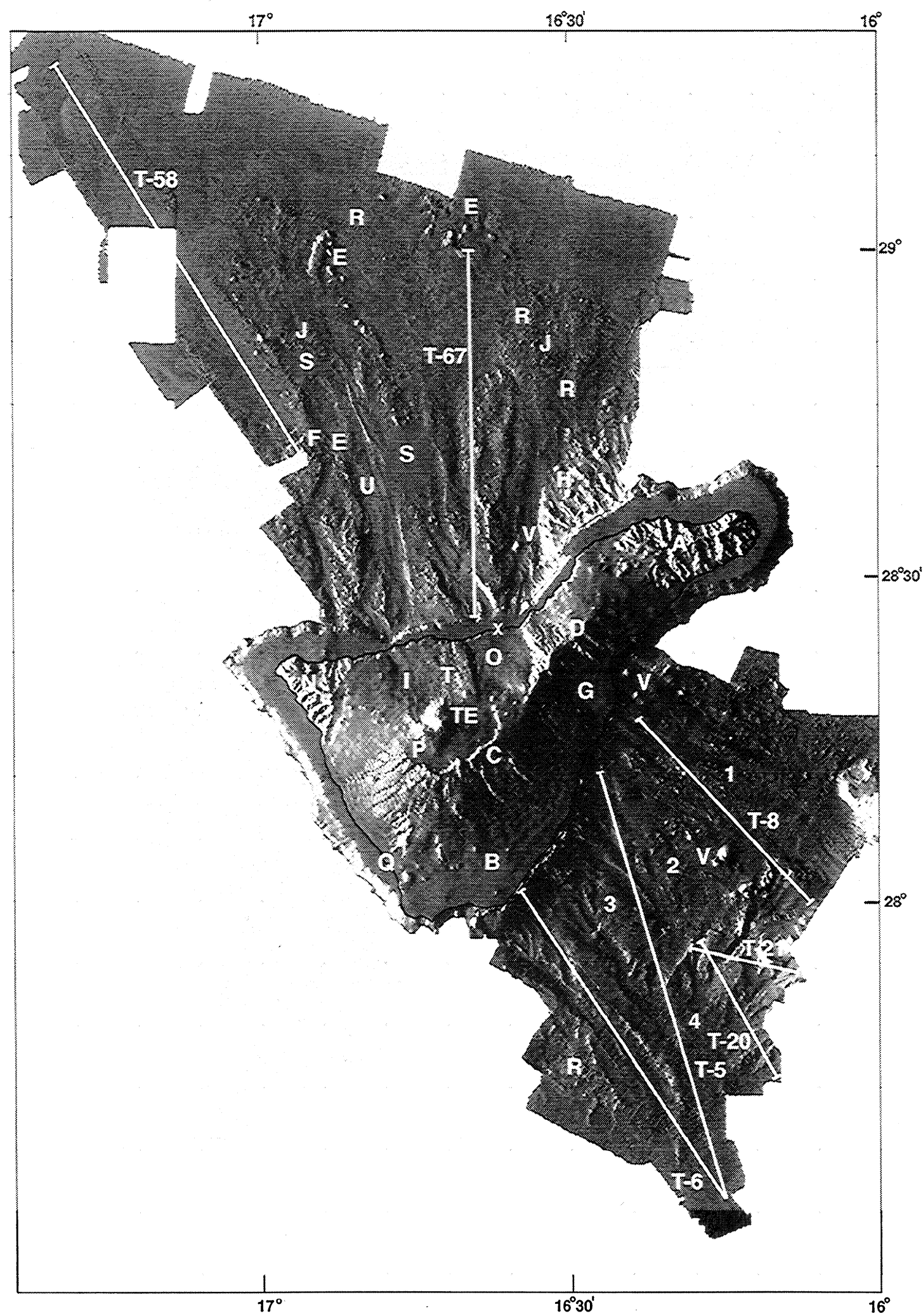

Figure 3b. Slope map of Tenerifc and offshorc arca showing locations of seismic reflection profiles (T-5 to T-67) and features described in the report. A, Anaga massif; B, Bandas Del Sur; C, Las Cañadas caldera; D, Cordillera Dorsal; E, exotic blocks; F, Teno massif offshore extension; G, Güimar Valley; H, channels on Anaga massif offshore extension; I, Icod Valley; J, fronts of secondary debris flows; N, Teno massif; O, Orotova Valley; P, Pico Viejo; Q, Roque del Conde massif; R, acquisition/processing artifact; S, no data; T, Tigaiga massif; TE, Teide; U, ridges; V, seamounts; X, Los Roques Islands; 1-4, morphologic provinces of the southeast slope. Note that the northern rim of Las Cañadas caldera is missing. 


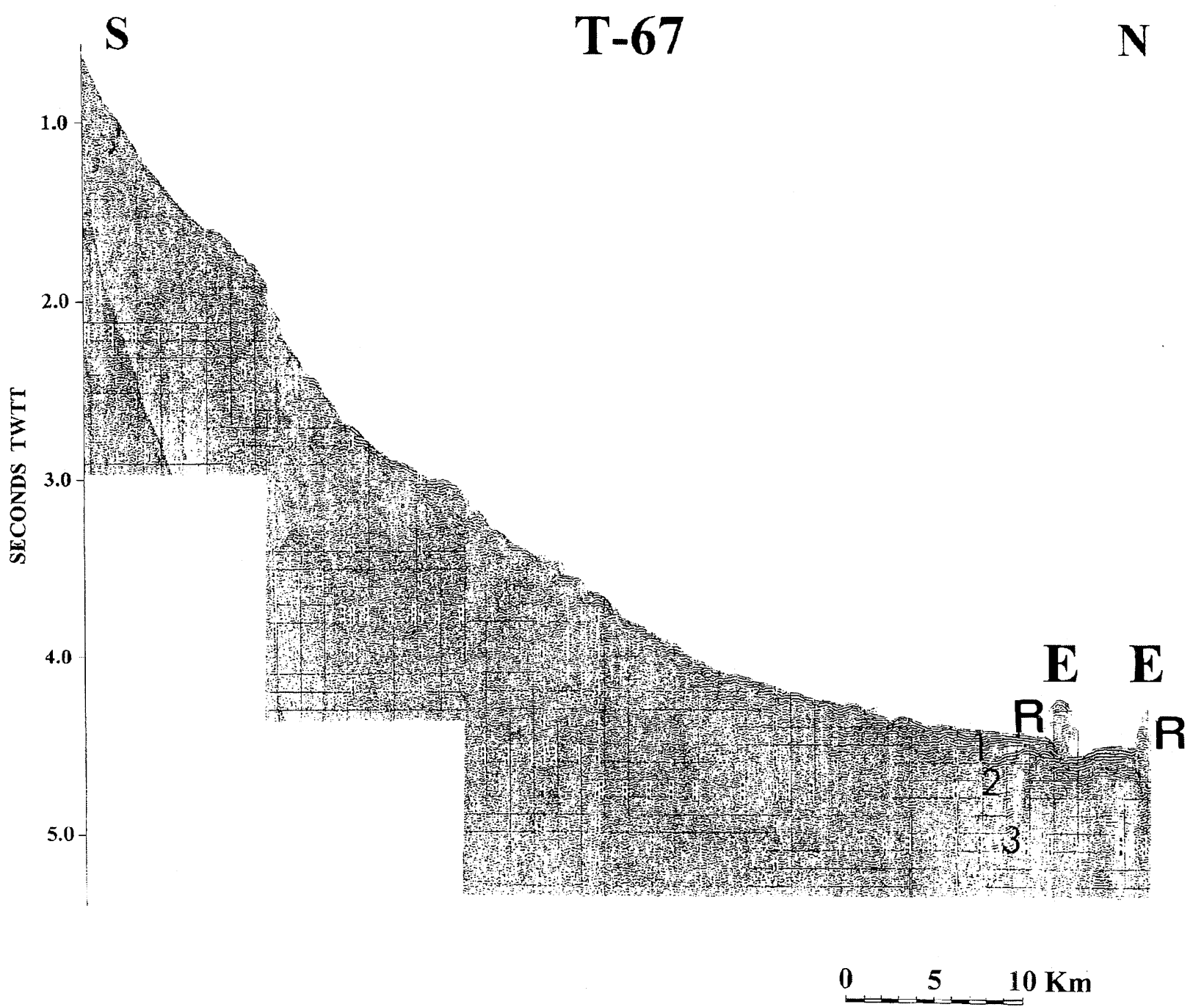

Figure 4. Seismic reflection profile T-67 cutting obliquely across the insular slope. The hummocky surface of the debris avalanche deposits imaged by this profile is so reflective that it masks the internal structure of the avalanche. Three depositional sequences can be identified at the seaward edge of the fan along this profile. Note exotic (E) boulders at the seaward end of profile and the erosional low around the periphery of the larger block. This low either marks the trail that the block followed to its final resting place or was formed by subsequent debris or by bottom current erosion after the block came to rest. $\mathrm{R}$ indicates possible reflectors in exotic blocks, suggesting that they may be stratified. See Figure $3 b$ for location of the profile.

consisting of numerous channels incised on the upper slope (Figure 3a). These channels merge downslope into a single low. The boundary betwecn the cast channcl and Anaga massif is marked by an irregularly faced scarp hundreds of meters high, oriented north-south with a gradient in excess of $40^{\circ}$. Along the axis of this channel is a circular high (V, Figure $3 b$ ) north of which is a lenticular-shaped high consisting of several lobes supcrimposed on onc another. The channel maintains its width downslope, and its mouth is an irregularly surfaced lobe onlapping the northern edge of Anaga massif. Roughness of the lobe is due to the presence of many small topographic highs. To the northwest of the lobe is a group of much larger highs in a field of smooth topography. At the hcad of the channel off Tigaiga massif, on the western side of the Orotova Valley, are two box-shaped canyons. These canyons incised on the upper slope are separated by a prominent spur (Figure 3a). Downslope from the canyons is a steep-sided channel which curves downslope and dies out before reaching the base of the lower slope. The divide between this channel and the one to west is a triangle-shaped high whose surface is smoother than the other divides. The channel west of this high has an amphitheater-like head downslope of which is an irregularly shaped high dividing the channel in two. The slope along the contact between the channel and the rough terrain in the vicinity of the Teno massif is subdued and irregular with a gradient between $25^{\circ}$ and $35^{\circ}$ (Figure $3 \mathrm{a}$ ). This channel first tends to narrow as it is constrained between the highs east and west of the low but widens downslope again as it flows beyond the confining highs. The channel between the westernmost high and the Teno massif is somewhat curved with its northern end being incised on the rough surfaced high adjacent to the Teno massif beyond which the channel merges with the one off the western side of Icod Valley. The floor of valley next to Teno massif is disrupted by arcuate curved steps (J, Figure $3 \mathrm{~b}$ ); the presence of longitudinal narrow ridges which undulate downslope and are subparallel to one another adds to the topographic complexity 

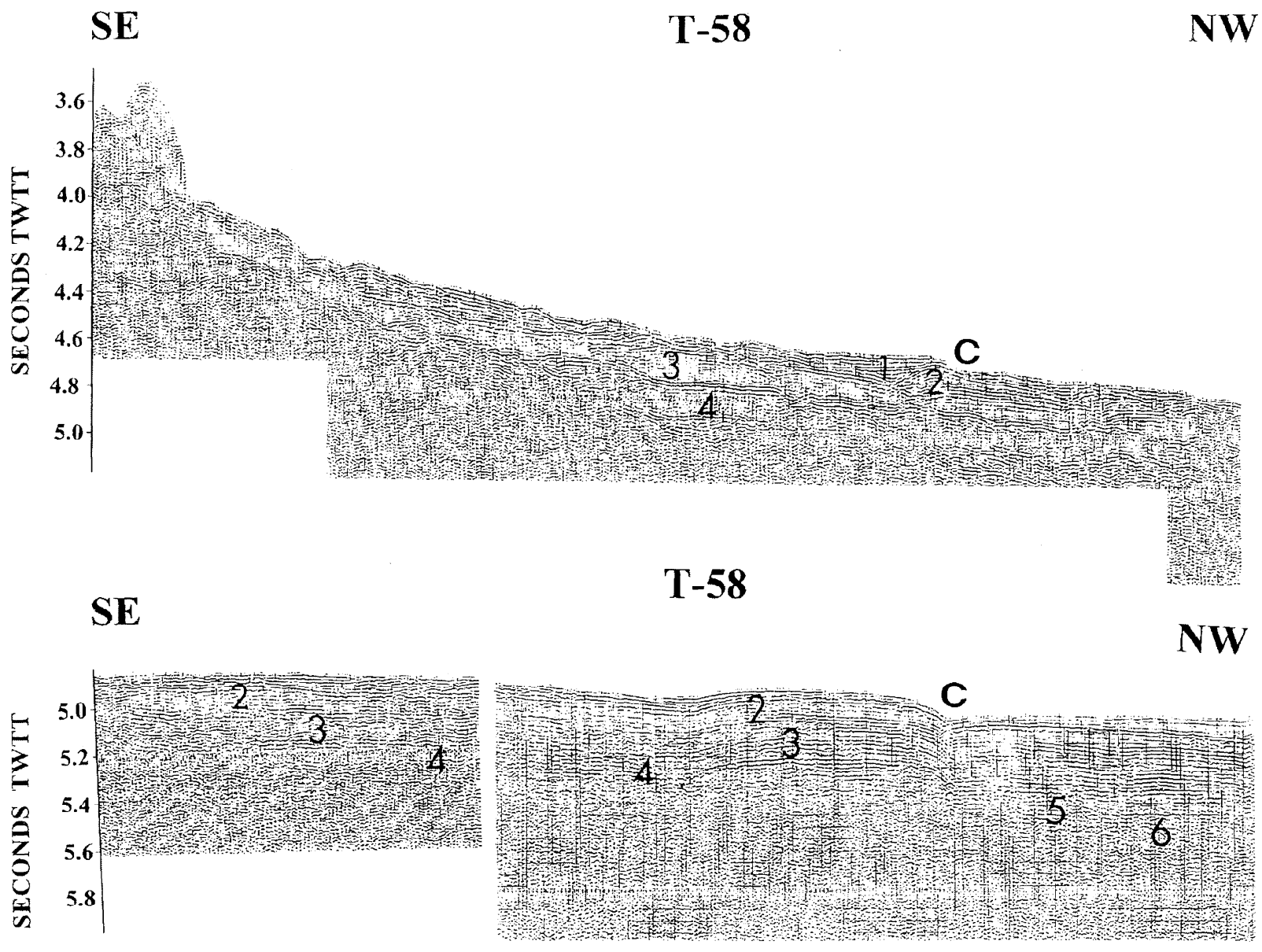

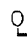

$10 \mathrm{~km}$

Figure 5. Scismic reflection profile T-58 off the Teno massif (T) imaging the sediment sequences on the apron at base of slope. At least six sequences are imaged on the apron by this profile. $\mathrm{C}$ indicates channels crossed obliquely by the profile. See Figure $3 b$ for location of profile.

of this channel and the one to the west (U, Figure $3 b$ ). The ridges on the channel off the west side of Icod Valley are quite narrow, but those immediately to the east are noticeably broader, and their crests are speckled with trains of small highs.

At the base of the insular lower slope is an extensive sediment apron (Figure 3a). On the surface of this apron are a network of circular to elongate highs with reliefs of 20 to $200 \mathrm{~m}$ and lengths of $<1$ to $8 \mathrm{~km}$ and depressions with reliefs of about $50 \mathrm{~m}$. As previously mentioned, most of these highs are at the northern ends of the rough surface highs on the lower slope. Some of the larger highs are oriented parallel to the slope gradient, but others are nearly at right angles to them. Backscatter amplitude recordings obtained with the EM-12 system and the computer-generated slope maps indicate that these highs are quite extensive on the sediment apron. Around the periphery of the bigger blocks are topographic lows. Other features scarring the surface of the apron are circular depressions and hummocks protruding above the surface. Three fans form the apron, one north of the Anaga massif and two others between the Anaga and Teno massifs. The curved edges of some of these structures appear to be segmented as though each fan is constructed of smaller secondary lobes, like secondary lobes on a bird's foot delta.

A seismic reflection profile of the fan along the west side of the apron shows its surface to be undulating to hummocky (profile T-58, Figure 5). This terrain terminates upslope on the Teno massif at a depth of $4 \mathrm{~s}$ or $3000 \mathrm{~m}$ (T-58, Figure 5). The profile images at least six acoustic sequences separated by hiatuses beneath the fan with the seafloor hummocks forming the surface of unit 1 , the youngest of the sequences. This unit which is about 50 to $100 \mathrm{~ms}$ thick (or $45-90 \mathrm{~m}$ assuming a velocity of $1.8 \mathrm{~km} / \mathrm{s}$ for the sediments) pinches out at a water depth of $3680 \mathrm{~m}$ on a high along the landward end of unit 2 . Its surface irregularities are more suggestive of emplacement by a debris flow than by a turbidity current, with the low relief of the irregularities suggesting emplacement at the distal end of such a flow. Unit 2 can be traced across much of the fan before pinching out at a depth of $3680 \mathrm{~m}$, and unit 3 extends from the rough topography near Teno massif (left side of profile) to the seaward edge of the fan where it is partially eroded by a channel crossed obliquely by the profile (C, Figure 5 ). Beyond this channel is a well-stratified sequence dipping northwestward. On the inner edge of the fan, unit 3 is underlain by unit 4 , and its outer edge is underlain by units 5 and 6 . Lack of penetration makes it impossible to determine the stratigraphic relationship between units 4 and 5 , although they may be coeval, with unit 6 being the oldest unit imaged by the seismic profile. Along seismic reflection profile T-67 (Figure 4) the 
surface of the fan seaward of Orotova Valley is hummocky (suggestive of a debris flow rather than turbidity currents) and acoustically opaque. Along its scaward cdge, however, the seismic reflection profile displays three sequences. The most striking features imaged by this profile are the two highs at the end of the profile. Although obscured by hyperbolic echoes, the highs, which are located to one side of the profile track, appear to be stratified (R, Figure 4).

\subsection{Sediment Failures on Northwest Margin}

All in all, the morphology of the region between seaward extensions of the Anaga and Teno massifs is a mirror image of the topography of debris avalanches and flows described from land and submarine volcanoes (Figures 3a and 3b) [Lipman et al., 1988; Moore et al., 1989; Holcomb and Searle, 1991; Normark et al., 1993; Wolfe et al., 1994]. It is this similarity that led Watts and Masson [1995] to infer that the whole region of rough topographic welts and channels extending downslope between the Anaga and Teno massifs was created by gravitational processes. Our investigation supports such an interpretation. Watts and Masson [1995] showed that this massive slope failure trends roughly northerly, reaching its maximum width near $29^{\circ} \mathrm{N}$ with its west flank extending to about $29^{\circ} 10^{\prime} \mathrm{N}$ and its eastern side extending to about $29^{\circ} \mathrm{N}$. Apparently, the displaced mass spread laterally to the east and west once it escaped the confines of the massifs. Not all the topography features displayed by the northwest slope, however, are the creation of slope failure. One of these nonslope failure features is the radiating channels on the seaward extension of the Anaga massif (H, Figure 3b). Watts and Masson [1995] stated that this radial topography resembles the morphology displayed by Tenerife onshore and the submarine canyons on the flanks of Oahu and Molokai [Coulbourn et al., 1974; Moore et al., 1989]. This similarity led them to propose that the submarine topography, despite its depth, was eroded subaerially. At the time the canyons were eroded, the northwest flank of Tenerife was above sea level, and the island subsided, drowning the canyons. However, as previous studies have demonstrated, morphology is not a reliable criterion to use in determining the origin of submarine canyons.

The bathymetric and seismic reflection data obtained during the present investigation indicate that the failures on the northwest slope took three forms: debris avalanches and/or creep, an elastic flow (the rough terrain of lower slope); debris flows (channels) (where the displaced material disintegrated into smaller pieces and the flow changed from elastic to plastic), and turbidity currents (viscous flows, apron at the base of the slope). The steps in the valleys in the lower slope that are convex downslope (J, Figurc $3 b$ ) represent secondary flows on the more massive structures. The narrow and steep ridges along the margins and within the box-shaped channels may be either the product of compression or scour. If they are compressional highs, they were created by velocity differences in the adjacent debris flows which led to the elevation of the sediments above their surroundings. Compressional ridges have been reported from the Mount St. Helen avalanche [Voight et al., 1981], off British Columbia [Prior et al., 1982], and off Norway [Bugge et al., 1988]. 'The slide described by Prior et al. [1982] is about $5 \mathrm{~km}$ long and less than $2 \mathrm{~km}$ wide, whereas the composite slope failure deposit off Tenerife is about $40 \mathrm{~km}$ long and ncarly $20 \mathrm{~km}$ wide. Thus similarities in the morphologic grain of both slides indicate that it is the physical processes of flow which control the morphology of a debris flow, not its dimension or the material involved in the slide.

The debris flows on the slope changed downslope into a viscous fluid flow in the form of turbidity currents which constructed a massive apron of coalescing fans at the base of the slope. The surface of the apron is disrupted by hummocks and lows which may represent grabens/horsts formed as the result of latcral spreading within the apron [see Voight et al., 1981]. In our survey we can identify three massive fans within this apron at the distal ends of the debris flows. The fan at the western end of the apron trends northwestward and protrudes $15 \mathrm{~km}$ beyond the rest of the main part of the slope failure. The rest of the apron front trends east-west with two fans extending about $5 \mathrm{~km}$ north of the general front. Our data also demonstrate that the fan at the western end of this apron is made of at least six turbidite sequences, indicating that catastrophic slope failure did not take place as a single event but as a series of distinct failures. Also associated with these distal deposits are small highs which tend to be concentrated on the distal ends of the topographic welts on the lower slope. We infer that these isolated highs are not in place but were transported downslope from their original positions. The configuration of one of these fans, ncar $16^{\circ} 40^{\prime} \mathrm{W}$, is controlled by a chain of the exotic blocks. This suggests that the blocks were deposited before the turbidity currents triggered by the debris flows constructed the apron at the base of the slope. We interpret these isolated highs as exotic blocks transported by the debris avalanches resulting from the slope failurc on land. In the vicinity of some of the blocks, there are erosional lows that are the result of subsequent differential erosion by bottom currents, define the passage taken by the blocks to their final resting place, or were eroded by later debris flows. In the absence of data which would allow us to define the flow processes we are unable to determine the mechanics involved in the transport of the blocks. The blocks could have glided to their present sites with the excess pore water pressure of the displaced deposit acting as a lubricant as in the Storagga slide off Norway [Bugge ct al., 1988]. Possibly, blocks were carricd cither within the flow or along its surface, being supported by a matrix of fine sediment as described by Lee et al. [1993] for slope failures in the Economic Exclusive Zone of the United States. Whatever the transport processes, the blocks appear to have retained their identity during downslope displacement, indicating that the blocks were more resistant to the internal shear of the flow than the other material making up the debris flow. Some of the blocks appeared to have had enough momentum to outrun the main part of the flow.

From bottom profiles constructed from the swath bathymetry, Watts and Masson [1995] inferred that the sediment failure deposits on 'Tenerife's northwest slope are concave up with steeper slopes on the landlord than on the seaward side and that the deposits have been built up by about $700 \mathrm{~m}$ and outward by at least $70 \mathrm{~km}$ and that they have an area of 5500 $\mathrm{km}^{2}$ and a volume of about $1000 \mathrm{~km}^{3}$. Our estimates are comparable to those of Watts and Masson. We calculated that the onshore area covered by the debris avalanche and/or creep was $194 \mathrm{~km}^{2}$ and offshore area covered by the debris flow and associated distal fan was $3923 \mathrm{~km}^{2}$. Gallcries dug into the avalanche deposits on land suggest that an assumed thickness of $500 \mathrm{~m}$ for these avalanche debris is not unreasonable, yielding a volume of $100 \mathrm{~km}^{3}$ for the onshore deposits. The sparse seismic reflection data offshore suggest that the avalanche debris/debris flows and postfailure deposits, if present, may 
Table 1. Area and Volume of Debris Flows, Ash Deposits, and Sediment Drifts

\begin{tabular}{|c|c|c|c|}
\hline Region & $\begin{array}{l}\text { Area, } \\
\mathrm{km}^{2}\end{array}$ & $\begin{array}{c}\text { Thickness, } \\
\text { Km }\end{array}$ & $\begin{array}{l}\text { Volume } \\
\mathrm{km}^{3}\end{array}$ \\
\hline \multicolumn{4}{|l|}{ Northwest region } \\
\hline Orotova Valley & 72 & 0.5 & 36 \\
\hline Tigaiga massif & 31 & 0.5 & 19 \\
\hline Icod Valley & 91 & 0.5 & 46 \\
\hline Insular slope & 3923 & 0.3 & 1177 \\
\hline Total & & & 1276 \\
\hline \multicolumn{4}{|l|}{ Southeast region } \\
\hline Güimar Valley & 73 & 0.5 & 37 \\
\hline Bandas Del Sur & 800 & 0.1 & 80 \\
\hline Dorsal scrics, SW of Güimar & 60 & ? & ? \\
\hline $\begin{array}{l}\text { Güimar Valley offshore } \\
\text { extension }\end{array}$ & 407 & 0.3 & 122 \\
\hline "Dorsal" volcanics offshore & 620 & 0.3 & 186 \\
\hline $\begin{array}{l}\text { Bandas Del Sur offshore } \\
\text { extension }^{c}\end{array}$ & 1894 & 0.3 & 586 \\
\hline $\begin{array}{l}\text { Sedimentary drift } \\
\text { Total }^{d}\end{array}$ & 959 & 0.2 & $\begin{array}{r}192 \\
2481\end{array}$ \\
\hline
\end{tabular}

${ }^{\mathrm{a}}$ Areas of units were estimated by tracing their outlines on paper, cutting and weighting them, and converting their weights into areas by dividing them by the weight of a known area.

${ }^{b}$ The thickness of $0.5 \mathrm{~km}$ for the land unit is based on the estimate by Bravo [1962] that the avalanche breccia on land is $>350 \mathrm{~m}$ thick. The thickness of the debris flow is based on the seismic reflection profile data using a $1.8 \mathrm{~km} / \mathrm{s}$ velocity to convert the travel time to kilometers. In the absence of an adequate database, all values are gross estimates.

${ }^{\mathrm{c} A}$ mixture of volcanic and nonvolcanic pelagics.

${ }^{\mathrm{d}}$ Total includes the slope failure deposits, the turbidites and sediment drifts downslope, and the postfailure volcanics and detrital sediments.

have an average thickness of about $300 \mathrm{~m}$, yielding a volume of $1177 \mathrm{~km}^{3}$ for these deposits, resulting in a total volume of 1276 $\mathrm{km}^{3}$ (Table 1).

In contrast to the catastrophic features on shore which are obscured by latest Pleistocene and Holocene volcanics, most of the surface of the offshore structures appears pristine; that is, the sediment cover is too thin to be discerned by the seismic reflection profiles with a resolution of about $10 \mathrm{~m}$. Watts and Masson [1995] also stated that the eastern part of the debris avalanche/creep/debris flow/turbidites is correlated with the $0.8 \mathrm{Ma}$ Orotova Valley (dated $0.4-0.3 \mathrm{Ma}$ by J. M. Navarro Latorre (personal communication, 1996)) and the western part with the Icod Valley. They also inferred that whercas castcrn part of the offshore slope failure may have been created as a result of a series of near-synchronous displacements, the western section may reflect events that took place over a longer time span, from 1.2 to $0.17 \mathrm{Ma}$. They also stated that such supposition may be supported by their multibeam and GLORIA data which show that the eastern boundary is more clearly imaged than the western one. They assumed that this difference is the result of a thicker sediment cover on the western part of the debris flow. Our data do appear to support such a scenario as the younger volcanics on the Orotova valley extend onto the slope but terminate just beyond the coast in the vicinity of Los Roques Islands (X, Figure $3 b$ ). The younger volcanics in Icod Valley, however, may extend to the shelf's outer edge. This supposition on our part needs to be verified. Our data do indicate, however, that part of the slope failure deposits is mantled by volcanics originating within the slope itself. Such a cover was documented within the channel next to the Anaga massif. This lava flow originated in a volcano $(\mathrm{V}$,
Figure 3b) near the head of the channel and partially covers the debris in this channel. It is this lava cover that we infer to be responsible for differences in seafloor roughness between the eastern and western sides of the debris flows, not a thicker sediment cover on the west as postulated by Watts and Masson [1995].

Although the structures offshore are aligned with the onshore ones, topographic continuity hetween ()rotova and Icod Valleys and the insular slope flows is not supported by Watts and Masson's [1995] or our data; the onshore and offshore structures are separated by a north facing, 100-600 m high with a gradient of $4^{\circ}-16^{\circ}$. We infer that this slope is the front of the debris avalanches and/or creep filling the valleys on land. A similar 400-m-high breakaway area scarp also separates the Golfo depression in Hierro from El Golfo debris flow offshore and the Grand Bule on land and the main submarine slide in Piton de la Fournaise, Reunion Island, in the Indian Ocean [Lénat et al., 1990]. Masson [1996] proposed that the scarp off Hierro may be a seaward continuation of the 900-m-high scarp at the head of the Golfo depression; possibly, the offshore scarp off northwest Tenerife represents a similar extension of the headwall of the Orotova Valley on the Cordillera Dorsal and the side of the Las Cañadas caldera at the head of the Icod Valley. Thus the offshore scarp together with minor undulations in the Orotova Valley represent normal fault scarps generated in the upper tensional regime of the massive slides extending from the Cordillera Dorsal to the seaward flanks of the Las Cañadas volcano and are comparable to the structures described by Moore and Mark [1992] from the island of Hawaii. Inowever, the structures in IIawaii are concave seaward and limited to the debris flow structures, whereas those in Tenerife are linear and extend beyond the structures.

We are a proposing a different scenario that one described by Watts and Masson [1995], in which not all the features offshore are a direct result of the slope failures on land. Although we do not have an adequate seismic reflection coverage, we infer that the 100 - to 600 -m-high scarp on the upper slope on the northwest side of Tenerife defines the front of the debris avalanche and/or creep deposits on land and the postfailure volcanics filling the Anaga and Icod de los Vinos Valleys. The flat top of this front and the one along the southeast coast probably are the result of wave erosion during Pleistocene glacially induced regressions. Part of the detritus created during this erosion must have been deposited on the slope beyond the platform, and the rest must have been deposited along the shore. As the platform became wider with time, its offshore contribution must have slowly diminished until most of the detritus was deposited along the shore. An edge termination of 100 - to 600 -m-high slope with a gradient as high as $16^{\circ}$ for the debris avalanche or rockfall filling the Orotova $(10$ $\mathrm{km}$ by $8-6 \mathrm{~km}$ and $0.5 \mathrm{~km}$ thick) and Icod $(10 \mathrm{~km}$ by $11-10 \mathrm{~km}$ and $0.5 \mathrm{~km}$ thick) is not unrealistic. The much smaller, $2 \mathrm{~km}$ long, 1-4 km wide, and 30-60 m thick rock-avalanche breccia with its gravity-driven glide blocks in the Shadow Valley Basin, eastern Mojave, California, for example, has a 20-30 m high termination slope with a gradient of $10^{\circ}-30^{\circ}$ [Friedmann, 1997]. We further speculate that the areas of rough topography north of this scarp represent a matrix-rich poorly sorted chaotic water-rich debris avalanche associated with the seaward edge of the debris avalanche and/or creep. Thus the upper slope may represent the boundary between the more dense debris avalanche and/or creep deposits onshore and the upper slope and the water-rich debris avalanche on the lower slope. Part of this 
debris also may have been deposited during the erosion of the platform on the top of the sediment front. Similar frontal extensions, but on a much smaller scale, also are associated with the rock-avalanche deposit front in the Shadow Valley Basin [Friedmann, 1997]. The isolated blocks found at the base of the lower slope also are part of these lobes associated with the earlier failure. They later obstructed the more recent debris flow and turbidity currents triggered by the flows. The more mobile channeled debris flows incised on the coarser debris and reaching the deep sca via channels are the creation of the failure of the front of the debris avalanche and/or creep. From our data it is impossible to determine when this failure of the front occurred; it could have taken days or years after formation; thus both are geologically contemporaneous. It is this sediment front that defines the breakaway slope of the debris flow and subsequent turbidity currents on the lower northwest insular slope. Failure of this sediment front appears to have occurred along discrete points documented by boxshaped and V-shaped canyons on the debris avalanche front between the Anaga and Teno massifs. This failure may have been due to a combination of rapid sediment accumulation and groundwater activity (spring sapping). That sapping may have contributed to the slope failures is suggested by the offshore groundwater discharges noted during an airborne thermal scanning radiometer survey off Tenerife [Williams and Fernandopulle, 1972]. Thus the slope sediments are the result of two slope failure events, one whose breakaway surface was on land and a younger one whose breakaway surface was on the upper slope. The acoustic stratigraphy of the fans at the base of the lower slope suggests that debris flows which eroded the broad channels incised on the debris avalanche deposits north of the front are the not product of a single event. They are the creation of numerous discrete failures of the front of the debris avalanche, failures which occurred at different places and times along the front between the Anaga and Teno massifs.

Another possibility is that the onshore and offshore the features were continuous in the past but recent vertical movements along the coast have led to their separation. If so, then the island has undergone recent uplift, an uplift due to the thermogenic event which led to the creation of the latest Pleistocene-Holocene Pico Viejo and Teide edifices within the Las Cañadas caldera and the volcanic structures along the Dorsal. The increase in relief of the offshore scarps westward in the direction of the Pico Viejo and Teide volcanoes suggests that heat has played a role in the uplift. Such an uplift is also supported by the large positive gravity anomaly centered in the Las Cañadas caldera, which indicates the presence of a large high-density body associated with a magma chamber [MacFarlane and Ridley, 1968] and the occurrence of intertidal fossils $8 \mathrm{~m}$ above sea level on the sea cliff on the northwest side of Tenerife [Bravo, 1952]. According to Bosshard and MacFarlane [1970] the presence of the magma body has upwarped basement under Tenerife about $1 \mathrm{~km}$ above the surrounding basement. Supposedly, two northeast trending faults, one extending from the northeast tip of Tenerife to Hierro and the other extending between Tenerife and Gran Canaria (Figure 1) [Bravo, 1962; Bosshard and MacFarlane, 1970], made possible the magma to rise in Tenerife [Bosshard and MacFarlane, 1970]. A third possibility is that the massive failures offshore were triggered by the faulting itself and are not related to the sediment failure. A fourth possibility would be that slope failure was a combination of faulting and sediment instability due to rapid buildup. Although the structural and stratigraphic information on the catastrophic failures, both on land and offshore, makes it impossible for us to ascertain the validity of the models described above, we tentatively support the first one.

\subsection{Morphology of Southeast Coast and Insular Margin}

The dominant morphologic features on the southeast coast of Tenerife are the (jüimar Valley on the northeast, a belt of "Dorsal" volcanics, and the broad volcanic fan, Las Bandas del Sur (Figure 1). The Güimar Valley is $8-9 \mathrm{~km}$ wide, has an amphitheater-shaped head, an area of $73 \mathrm{~km}^{2}$, a box-shaped cross section, and prominent side walls, and its relatively flat floor is mantled by latest Pleistocene-Holocene lavas of the Teido-Pico Viejo complex. Like Orotava Valley the floor of Güimar is covered by several volcanoes. The construction of two of these edifices at its mouth led to the eastward progradation of the shoreline, creating a prominent bulge along the coast and shelf-upper continental slope.

Bordering Güimar Valley on the southwest and paralleling its southeast trend is a zone of "Dorsal" volcanics (Figure 1). The width of this terrain, which ranges from about $1 \mathrm{~km}$ next to the Cordillera Dorsal to about $5 \mathrm{~km}$ along the coast, is made up of a series of northeast trending ridges made of two flows separated by an unconformity. The flows range in age from $0.87 \mathrm{Ma}$ below the unconformity to $0.84 \mathrm{Ma}$ below the hiatus [Ancochea et al., 1990]. Southwest of the "Dorsal" volcanic belt is the Las Bandas del Sur, a volcanic fan with an area of about $800 \mathrm{~km}^{2}$. According to Booth [1973], Las Bandas is a semiarid region composed mainly of pumice, ignimbrites and mudflows (lahars), basaltic scoria cones, and lavas which we estimate to have a volume of about $80 \mathrm{~km}^{3}$ (Table 1). Projecting above the general level of the fan are steep-sided erosional remnants of older basaltic lavas. The pumice and ignimbrite deposits in the fan, the product of many explosive episodes, consist of two sequences (Fasnia and Granadilla series) separated by basaltic volcanics or a soil up to $40 \mathrm{~cm}$ thick [Bryan, 1995]. The lower sequence or Fasnia series ranges in age from 21.19 to $0.13 \mathrm{Ma}$, and the upper sequence or Granadilla series is less than 0.06 Ma in age [Ancochea et al., 1990].

An isopach map of the Granadilla series displays a northwest trend with a thickness of $8-4 \mathrm{~m}$ along its axis and about $0.5 \mathrm{~m}$ along its flanks [Booth, 1973]. Seismic refraction measurements by the Instituto Epañol de Oceanografia and Geocisa of Spain show that the Granadilla cover along the coast is patchy, with its continuity being disrupted by wide areas of basaltic outcrops. Between these outcrops are local accumulations of pumice with thicknesses between 5 and $10 \mathrm{~m}$. The texture of the layer displays the same configuration as the isopach contours with the coarsest sediment having a median diameter greater than $16 \mathrm{~mm}$ along the crest of the sediment lobe and finer than $4 \mathrm{~mm}$ along its flanks. Booth [1973] has inferred that this coarse debris was transported to its present site from Las Cañadas volcano by northeasterly winds.

The morphology of the southeast margin of Tenerife is markedly different from that northwest of the island (Figures 3-6). Whereas the northwest margin faces the open sea (the Canary Basin), the margin on the southeast side of Tenerife is fronted by Gran Canaria (Figure 1). The narrow northeast oriented channel between these facing slopes is characterized by east-west to northwest oriented basement spurs at the base of the Gran Canaria slope, a northeast trending topographic low with two isolated highs northeast of these spurs. In contrast to the high-energy northwest coast, where the morphologic features are truncated by a sea cliff, those along the lower- 


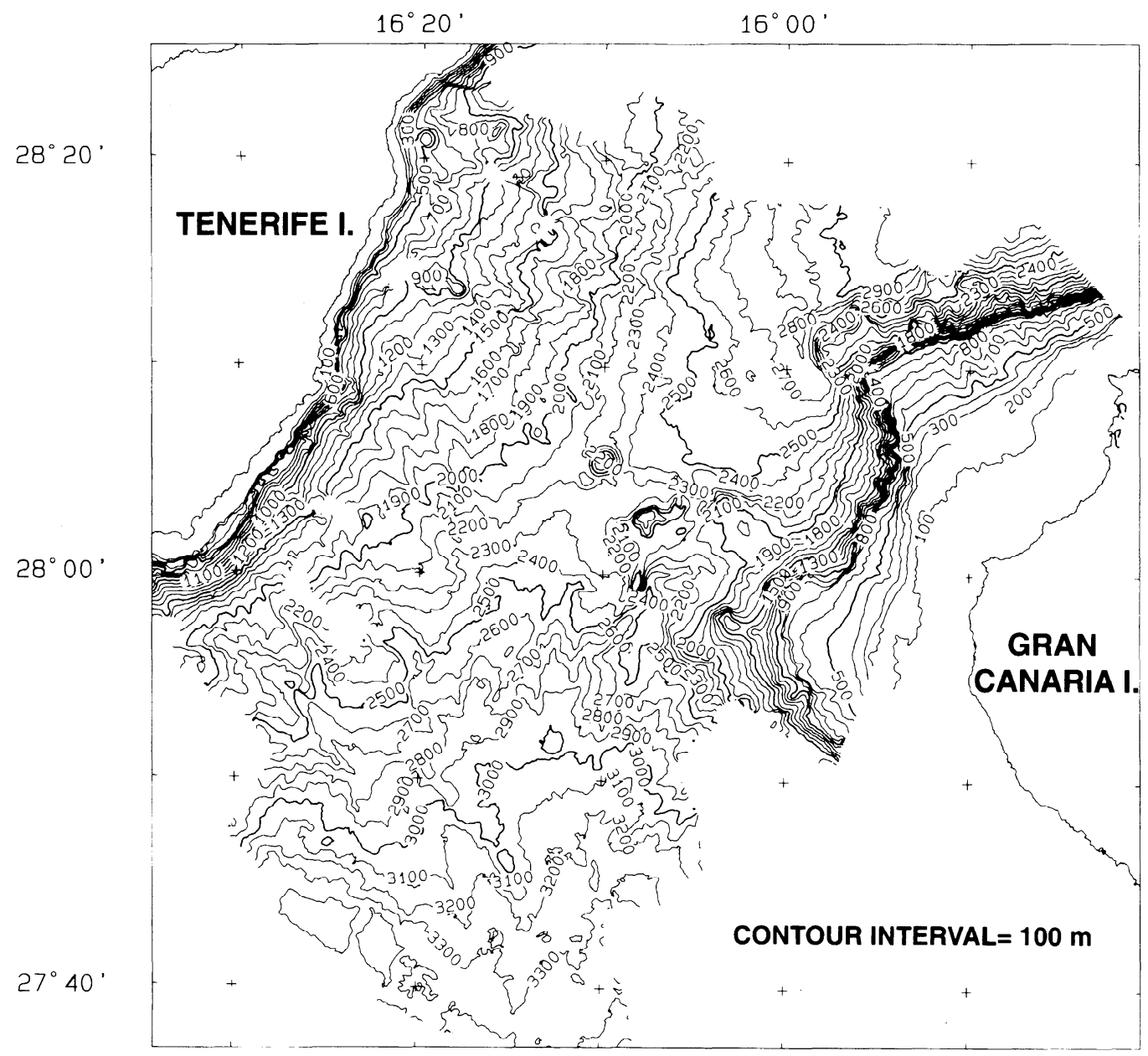

Figure 6. Chart of Tenerife's southeast slope based on swath bathymetric data. Contours are in meters.

energy environment of the southeast coast of Tenerife lack such a cliff or are bordered by one less than $20 \mathrm{~m}$ high. The wave-eroded platform cut during the Pleistocene glacially induced regressions bordering these features is narrow, averaging about $1 \mathrm{~km}$ in width. In contrast to the near absence of unconsolidated cover on the northwest shelf, a detailed seismic reflection profile survey of the shelf off the Las Bandas del Sur revealed the presence of significant sediment cover (Instituto Español de Oceanografia, unpublished data 1979). These sediments, whose source was Las Bandas del Sur, are thickest near the shelf's edge at a depth of $20-30 \mathrm{~m}$, reaching values in excess of $30 \mathrm{~m}$. The wedge thins landward on coastal exposures of basalt and seaward on the upper slope, along a chain of highs at a depth of $300600 \mathrm{~m}$, where basalt is also exposed. The geometry of the sediment accumulation is indicative of at least four depocenters which probably represent relict late Pleistocene deltas deposited when sea level was 120-130 m lower than today (Instituto Español de Oceanografia, unpublished maps, 1979). The other difference between the slopes is their seismicity. Whereas the northwest slope of Tenerife is aseismic, a northeast trending normal fault with a strong component of left-lateral transcurrent motion cuts obliquely across the southeast slope of Tenerife (Figure 1) [Dash and Bosshard, 1969; Bosshard and MacFarlane, 1970; Mezcua et al., 1990].

The southeast upper insular slope from the shelf's edge to a depth of $800-1800 \mathrm{~m}$ has a gradient of $15^{\circ}-16^{\circ}$ and the lower slope from $800-1800$ to a depth of $2500-3400 \mathrm{~m}$ has a gradient of $3^{\circ}$ (Figure 6 ). The upper slope segment displays little evidence of erosion toward the southwest but is incised by canyons toward the northeast. The presence of at least two 200m-high seamounts off Güimar Valley adds to the topographic irregularities of the slope in a northeasterly direction (V, Figure $3 b$ ). The lower slope also is characterized by low swells and valleys oriented northwest-southeast, a topography which dies out to the northeast. At the southwestern end of the present survey this undulating topography extends to a depth of about $3400 \mathrm{~m}$. The topographic features along the juncture of the Tenerife and northwest Gran Canaria slopes are aligned in a northeast direction, parallel to the strike of the insular slopes. These northeast trending features range from a swell-trough topography south of about $28^{\circ} \mathrm{N}$ to a low north of this latitude.

On the basis of the morphology displayed by the slope map and the internal reflection geometry imaged by the seismic reflection profiles, the lower slope off the southeast slope of Tenerife is divisible into four provinces: (1) off Güimar Valley, (2) southwest of the valley, (3) seaward of Las Bandas del Sur, and (4) along the contact between the Tenerife and Gran Canaria insular slopes (Figure 3). Province 1 off Güimar Valley is a broadly curved lobe with a hummocky surface and an area of $407 \mathrm{~km}^{2}$. Incised into the surface of this province is a narrow valley originating at the base of the upper slope. This $\mathrm{V}$-shaped low extends the width of the lower slope, dying out on a zone of rough topography. Whereas the upper lower slope seaward off Güimar Valley is relatively smooth, its morphology 


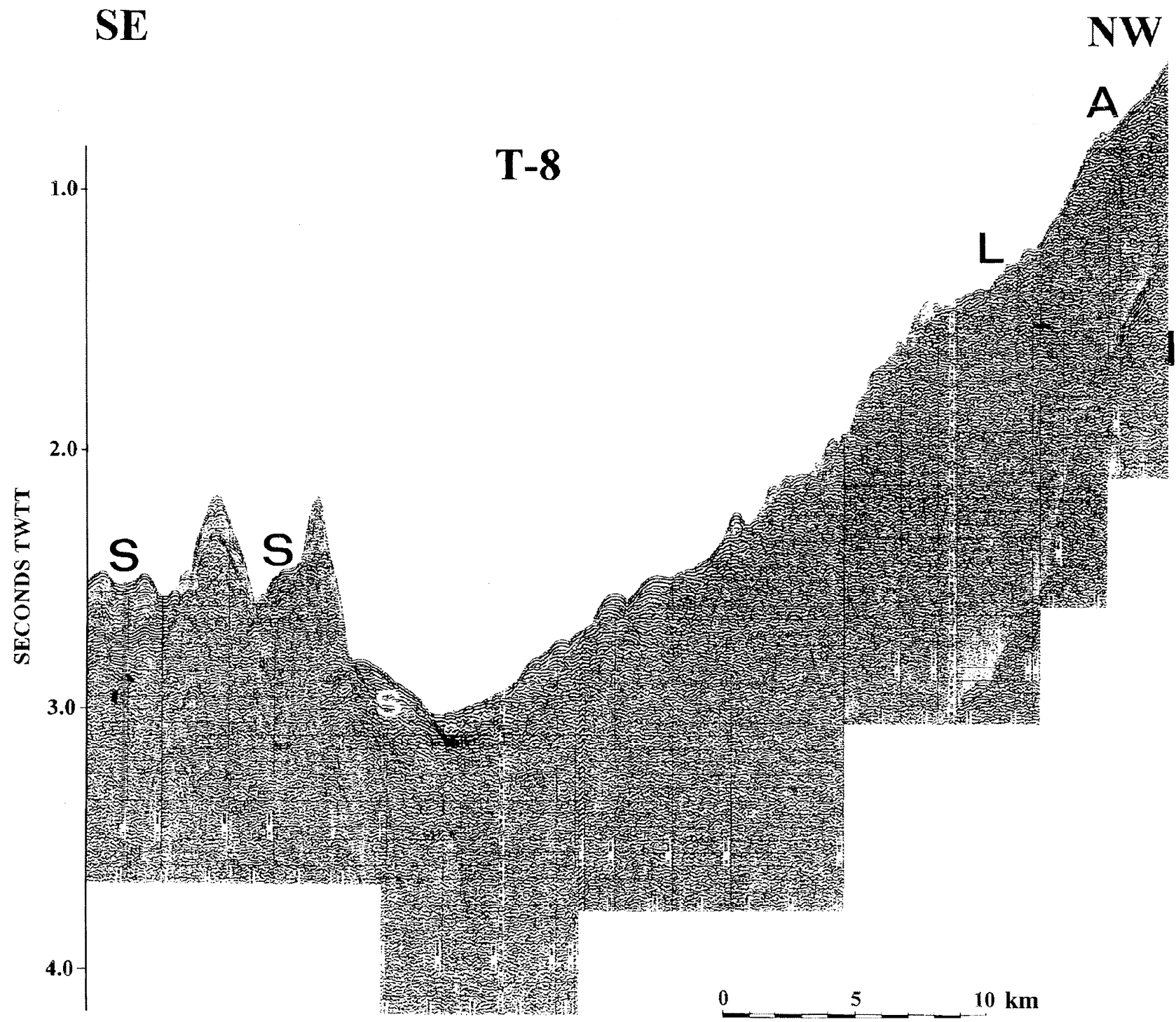

Figure 7. Seismic reflection profile T-8 of the debris avalanche in province 2. A, sediment wedge on outer shelf-upper slope; L, slump on upper slope. The volcanic hills on left side of profile, at the base of the Gran Canaria slope, are partially covered by sediment drifts $(\mathrm{S})$. See Figure $3 b$ for location of profile.

only being disrupted by two circular highs, the surface of the base of the lower slope is disrupted by a broad band of small highs. Northeast of Güimar Valley, off the Anaga massif, these highs extend nearly the whole width of the lower slope.

Seaward of the "Dorsal" volcanics separating Güimar Valley and the Las Bandas del Sur volcanic fan is province 2 with an area of $620 \mathrm{~km}^{2}$ (Figure 3). It is separated from province 1 by a box-shaped channel at the mouth of which is an irregular edged fan. Like province 1 , the morphology of province 2 is dominated by a field of irregular highs extending from the middle to the base of the lower slope extending southwestward from the channel between provinces 1 and 2 . At the southwest end of the rough topography is a $500-\mathrm{m}$-high circular high. The lower slope northwest of the field of irregular topography is smooth. Seismic reflection profile T-8 (Figure 7) cutting obliquely across the province displays a hummocky sea floor with a few rounded peaks rising above its general surface. The only evidence of stratification imaged by the profile is on the outer shelf-upper slope with a sediment prism pinching on the upper slope (A), some slump structures on the upper slope (L), a sediment-filled low at the base of the lower slope, and the sediments filling the lows on the rough topography of the Gran Canaria lower slope $(\mathrm{S})$.

Seismic reflection T-6 (Figure 8) recorded along the southwestern edge of the area of our present investigation clearly images the acoustic stratigraphy of province 3 , dominated by a northwest trending swell valley topographic grain. The acoustic basement (A) along this profile has a hummocky surface and can be traced the length of the profile. Resting on this acoustic basement on one of the lows in the province, near the center of the profile, is a sediment lens convex upward (1). Its internal structure is chaotic, and its surface is irregular. Along the sides of the valley is an irregularly surfaced acoustic transparent unit (2) displaying a thickness of as much as $0.7 \mathrm{~s}$ or $600 \mathrm{~m}$ using a sediment velocity of $1.8 \mathrm{~km} / \mathrm{s}$. This unit partially overlaps the lower debris flow. Profile T-5 (Figure 9) along the edge of one of the channels only images the younger transparent unit whose surface is irregular; its internal structure is also chaotic and rests on acoustic basement (A). At the distal end of the profile the reflectors of the transparent unit are better devel- 


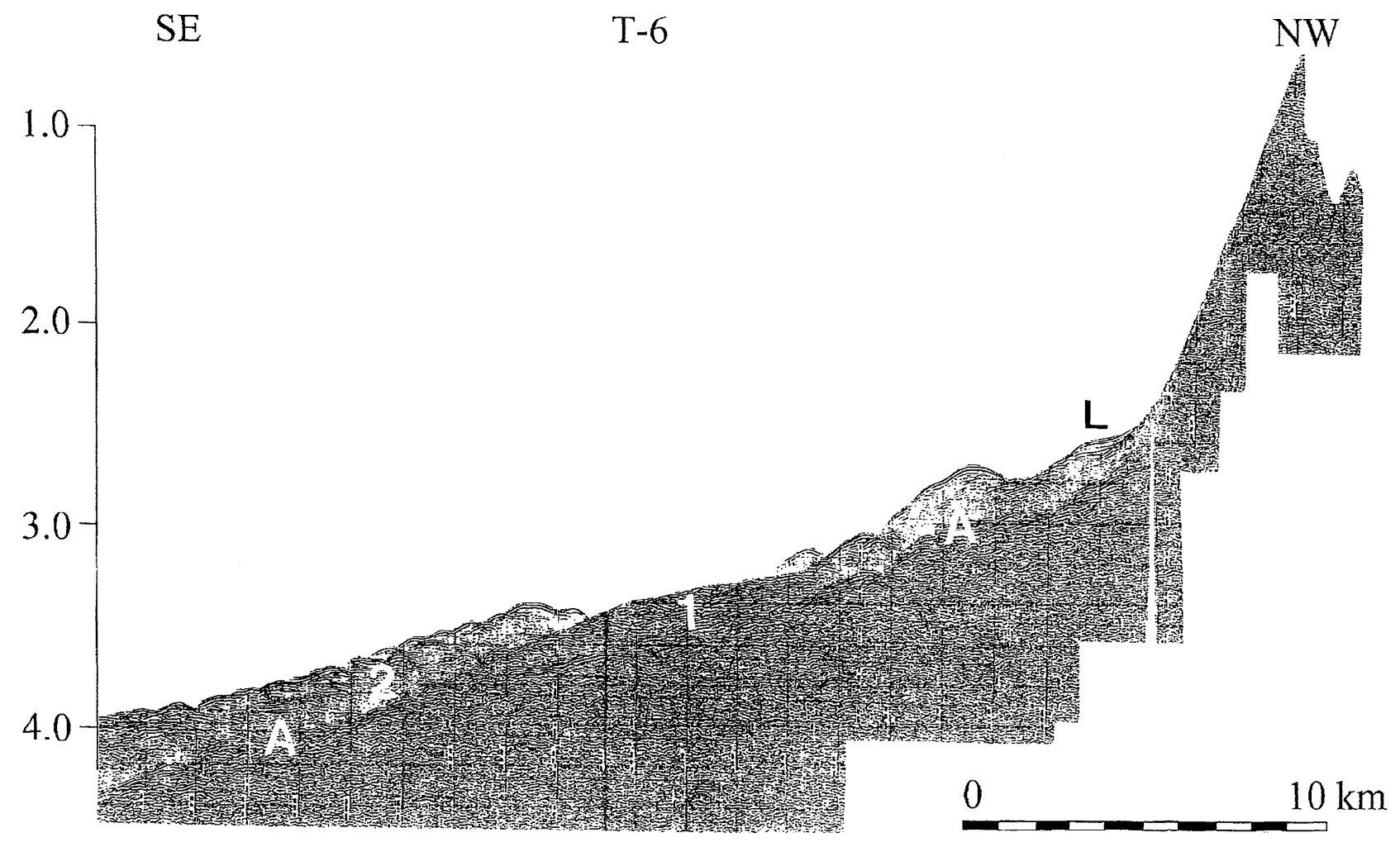

Figure 8. Seismic reflection profile T-6 along the west side of province 3 off Las Bandas del Sur. A, acoustic basement; L, slump structure at base of upper slope; 1, lower debris flow; 2, upper debris flow. See Figure 3b for location of profile.

oped, displaying a gentle dip toward the southeast. We infer from this that this segment of the profile is a fan. Subscquent to its construction, a low-relief northeast oriented channel was cut into the fan.

Province 4 along the boundary between the Tenerife and Gran Canaria slopes is marked by northeast trending grains (Figures 3 and 10). These clongate features are broadly undulating and are aligned parallel to the trend of the contact of the southeast Tenerife and northwest Gran Canaria slopes.

\subsection{Sediment Failures and Sediment Drifts on the Southeast Slope}

We estimate that debris avalanche and/or creep created during the formation of Güimar Valley has a volume of $37 \mathrm{~km}^{3}$ (Table 1). Like the debris avalanche and/or creep deposits on Orotova and Icod Valleys, those on Güimar Valley also are not topographically continuous with the failure deposits offshore but are separated by a 700-m-high slope slightly convex to the east. As on the northwest slope, we infer that the 700-m-high upper slope represents the front of the slope failure onshore and the rough terrain on the lower slope represents a tongue of more fluid debris avalanche and/or creep extending downslope from this front (Figure 3a). The failure deposit on the lower slope off Güimar is relatively continuous and is only incised by one V-shaped channel probably eroded by postfailure turbidity currents. The absence of channeled debris flows suggests that the debris avalanche and/or creep front did not experienced the extensive failure it did on the northwest slope. The occurrence of at least two circular highs seaward of Güimar Valley indicates that postfailure volcanism has been significant in the construction of the southeast slope. Postfailure sedimentation, via the numerous canyons cut on the upper slope, also has been important in the construction of the slope. That such detrital deposition was significant is indicated by the relatively smooth texture of the upper lower slope off Güimar Valley, a deposition which has buried the debris avalanche. Thus the ephemeral rivers in the Güimar Valley must carry an enormous volume of alluvium during the sporadic rainy season. These deposits are now reaching, or in the recent past have reached, the lower slope via the canyons cut on the upper slope. The absence of such a cover on the northwest slope suggests that the rivers on the wetter, northwest side of Tenerife are not significant sediment contributors offshore. Elsewhere studies indicate that ephemeral rivers like those in the (jüimar Valley can transport considerable detritus. In the Negev desert, for example, such ephemeral rivers have bedloads of 8.2 to $10.7 \mathrm{~kg}$ $\mathrm{m}^{-1} \mathrm{~s}^{-1}$ and suspended concentrations of $90,000 \mathrm{mg} \mathrm{L}^{-1}$ [Reid et al., 1994]. According to Laronne and Reid [1993], ephemeral desert rivers, such as those found in Güimar Valley, are not only more effective and less variable as sediment carriers than perennial ones, but they are also 400 times more effective in transporting coarse detritus. We estimate that the volume of sediment involved in the failure off Güimar and the postfailure volcanic/detritus is about $122 \mathrm{~km}^{3}$ (Table 1). Lack of samples does not allow us to determine the magnitude and extent of detrital contribution to province 1 nor how many of the highs on the sample surfaces are exotic blocks or volcanic structures.

The morphology of province 2, like province 1, was produced by debris avalanche and/or creep which originated in Güimar Valley and spread southwestward to the low between the Tcnerife and Grand insular slopes (Figure 3a). In province 2 the avalanche was modified by at least one channeled debris flow triggered by failures along the debris avalanche and/or 


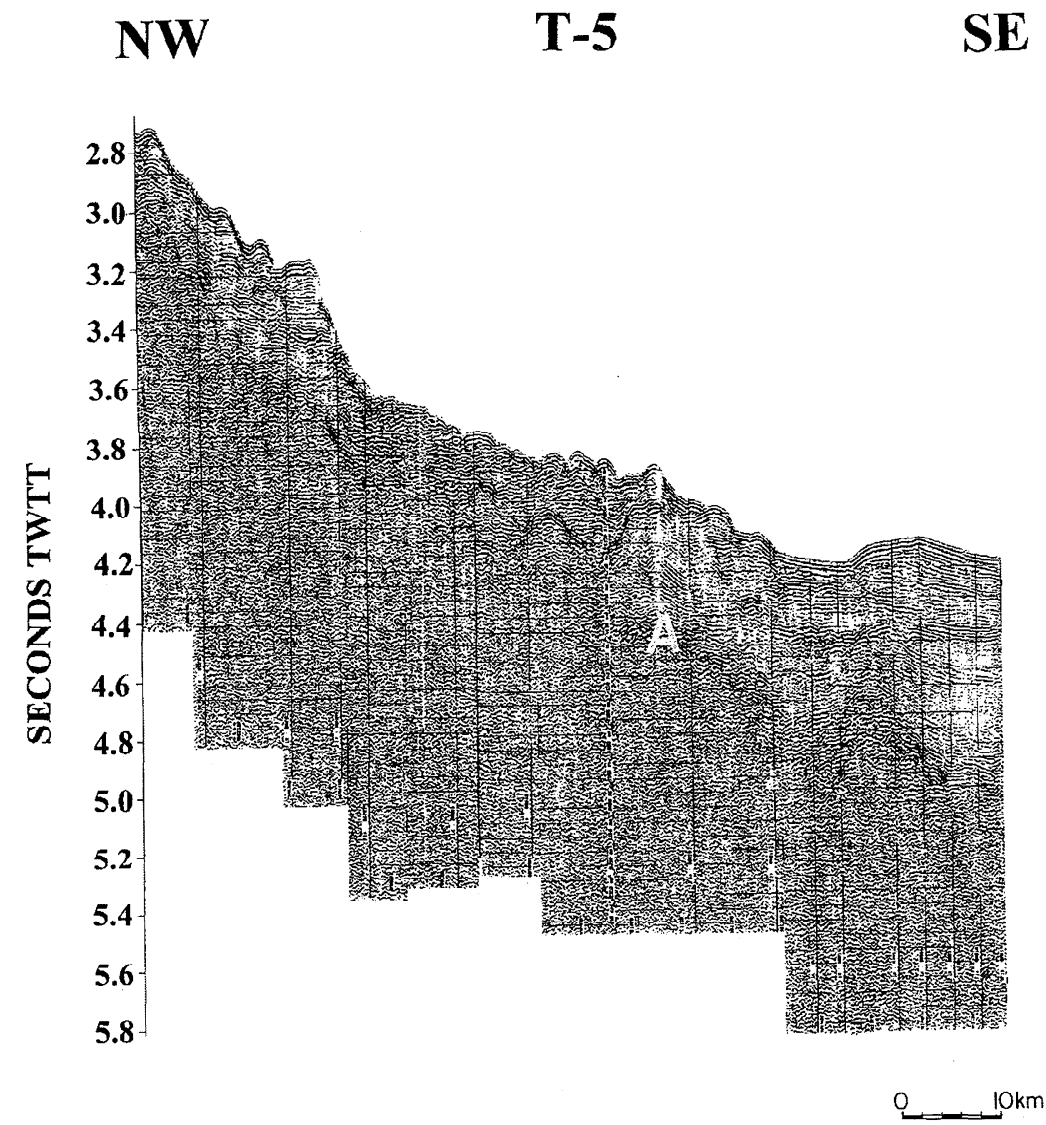

Figure 9. Seismic reflection profile T-5 of the lower slope on the east side of province 3 seaward of Las Bandas del Sur. Most of the structures displayed by this profile is the product of debris flow. Sediments on right of profile are undeformed and display a fabric suggestive of fan deposition. Since its construction the fan was cut by a channel whose northeast trend indicates it was created by along slope (bottom currents). These currents also modified the overbank deposits at the base of the Gran Canaria slope to the right of the channel. A, acoustic basement. See Figure $3 b$ for location of profile.

creep front (off the southwest edge of Güimar Valley) and its partial burial toward northwest by detritus from Güimar Valley and volcanic sediments from Las Bandas del Sur volcanic fan (smooth topography on the upper lower slope). The presence of a volcanic high at the distal end of the debris avalanche also suggests that as in province 1, postfailure volcanism has modified the debris avalanche. The debris avalanche, debris flows, and postfailure volcanic/detritus in province 2 have a volume of $186 \mathrm{~km}^{3}$ (Table 1).

Seismic reflection profile T-6 (Figure 8) demonstrates that the swell-valley terrain in province 3 is not the creation of deposition-erosion. As illustrated by this profile, the unit in the valley in the middle of the profile is lenticular in shape with its flanks overlapped by a rough surfaced acoustically transparent unit. The configuration of the unit in the valley suggests that the sediment is not a channel deposit, which would either be flat or convex downward, but a debris flow. The rough surfaced acoustic transparent unit, resting mainly on acoustic basement but overlapping the flanks of the lower debris flow, is another debris flow unit displaying evidence of slumping near the front of the Las Bandas del Sur volcanic fan (L, Figure 8). Differences in the surface morphology of these flows suggest that the lower flow with its smoother surface may have been more fluid than the upper one with its rough surface. Thus the swell-valley morphology of province 3 is the result of two partially overlapping debris flows with the topographic lows being aligned along the axes of the lower flow; that is, the topography lows in reality are sediment highs. The trends of the lows and lobes between them indicate that both flows probably originated from the $1700 \mathrm{~m}$ high front of the Bandas del Sur volcanic fan with the lower flow originating from a more a northeasterly direction. As documented by profile T-5 (Figure 9) the sediments of the upper debris flow grade downslope into a fan, indicating that at the base of the lower slope the younger debris flow had changed from plastic to viscous. We estimate that province 3 has an area of $1894 \mathrm{~km}^{2}$ and a volume of 586 $\mathrm{km}^{3}$ (Table 1).

The trends of the topographic features in province 4 indicate that they are not the creation of downslope processes. For example, the channel at end of profile T-5 (Figure 9), along the contact between the Tenerife and (Iran Canaria insular slopes, is oriented at right angles to Tenerife's insular slope. Thus it was the creation of along rather than downslope processes, i.e., bottom currents. The irregular surface of the overbank deposits southeast of this erosion low, which has resulted in recognizable buildup of the base of the Gran Canaria lower slope, also indicates that they have suffered modification by alongslope processes. The sediment accumulation at the base the Gran Canaria slope (profile T-8, Figure 7) also displays an internal morphology suggestive of deposition under the influence of bottom currents. Such a processes also is imaged by the seismic reflection profiles T-20 and T-21 (Figure 10) and pro- 

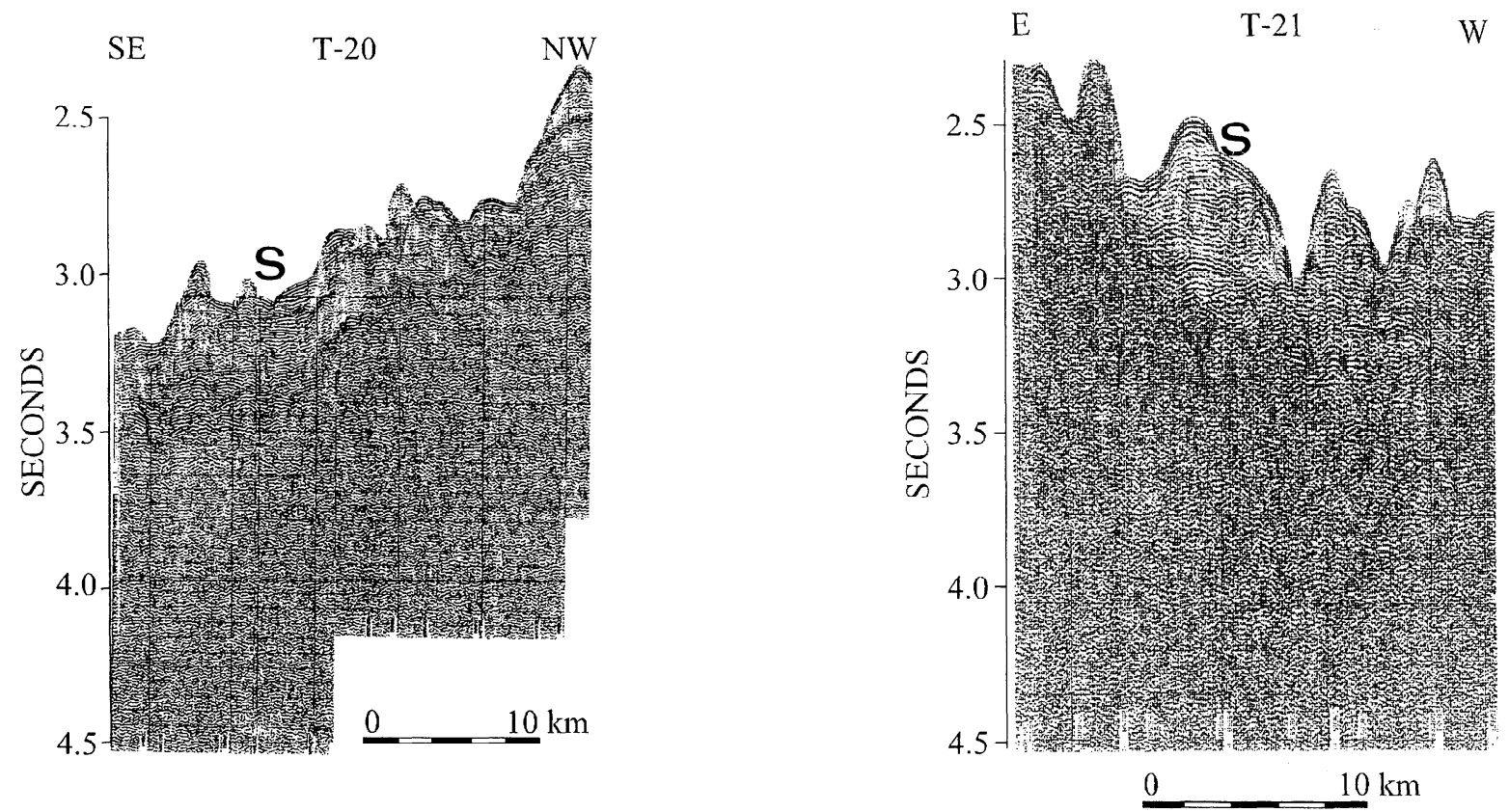

Figure 10. Seismic reflection profiles T-20 and T-21 of sediment drifts (S) along the contact between the Tenerife and Gran Canaria slopes. See Figure $3 \mathrm{~b}$ for locations of profiles.

files T-22 to T-25 (not included in this report). Results from the present investigation and the results of Ocean Drilling Program (ODP) Leg 157 [ODP Leg 157 Shipboard Scientific Party, 1995] indicate that these sediment drifts were molded out of volcaniclastic sediments reflecting the evolution, growth, and mass wasting of Tenerife and Grand Canaria. As these features occur above the upper surface of Antarctic Bottom Water (3900 m, ABW [Jacobi and Hayes, 1992]), they probably were sculptured by southerly flowing North Atlantic Deep Water (NADW) at a depth of 1500-3900 m. These currents are also responsible for the erosion of the channcl along at the distal end of the Tenerife volcaniclastic apron imaged by line $\mathrm{T}-5$ (Figure 9). The area covered by the sediment drifts is 959 $\mathrm{km}^{2}$, and the drifts have a volume of $96 \mathrm{~km}^{3}$ (Table 1 ).

\section{Summary}

The gcologic evolution of Tencrife and its offshorc cnvirons was controlled by Neogene volcanism, i.e., the age dependence of this volcanic load on the elastic thickness of the underlying lithosphere, climate, lithology, structural fabric, and bottom currents [Ancochea et al., 1990; Watts and Masson, 1995; this study]. Volcanic construction of Tencrife was in threc phases. The first phase, which took place in late Miocene and early Pliocene, 11.6-3.5 Ma [Ancochea et al., 1990], is represented by the Anaga, Teno, and Roque del Conde massifs in the northeast, southwest, and southeast corners of the triangular-shaped island. It is possible that during this and subsequent stages, slumping, avalanches, and debris flows were triggered on the flanks of the volcanoes and deposited on their peripheries. Such slope failures would not be unusual, as a significant amount of coarse volcaniclastic debris, for example, was transported to the deep sea for a distance of over $50 \mathrm{~km}$ during and soon after major periods of volcanic activity in Gran Canaria [ODP Leg 157 Shipboard Scientific Party, 1995]. However, no such deposits have been recognized in Tenerife, and if they exist offshore, they are buried by younger debris flows.

If such catastrophic events did take place, it would have resulted in major unloading leading to an additional uplift of Tenerife. Watts and Masson [1995] postulated that as result of this combined uplift, the island underwent extensive erosion during the quiescence period that followed the avalanche phase, an erosional event represented by the offshore valleys that are cut in the flanks of the Anaga massif. Watts and Masson [1995] further proposed that as a rcsult of the relaxation of this stress a few million years after the valleys were cut, the island began to subside and the valleys were drowned. However, in the absence of critical stratigraphic data, the origin of the offshore features remains in doubt; similarity to subaerial features is not a reliable criterion for the origin of submarine vallcys.

The next phase of volcanic construction took place in late Pliocene to mid-Pleistocene when the Cañadas volcano and Cordillera Dorsal and associated stratovolcanoes were constructed between the remnants of the late Miocene-early Pliocene volcanic structures. Failures of these volcanic structures led to the formation of the south draining Güimar at 0.7-0.6 $\mathrm{Ma}$, the north draining La Orotova Valley at 0.4-0.3 Ma, and the Las Cañadas caldera and north draining Icod de los Vinos Valley before 0.2 Ma. During the catastrophic failures of the northwest side of Tenerife a massive block about $10 \mathrm{~km}$ long and several kilometers wide and about $1 \mathrm{~km}$ thick, Tigaiga massif, was carried downslope by the debris avalanche and/or creep to its present position.

Our study indicates that the bulk of the debris avalanche and/or creep in Güimar, Orotova, Icod, and Güimar Valleys terminated near the present coast with their terminations being documented by a 100-600 m slope with a gradient of $4^{\circ}-16^{\circ}$. Evidence of reworking of the deposit along the northwest coast of Tenerife may indicate that the front of the failure ended in the vicinity of the shoreline. However, this reworking may have taken place long after the failure occurred. Thus it is not an indication of the location of the shoreline at that time. Extending downslope from these slopes are lenticular lenses of more fluid debris avalanches which can be traced to the base of 
the slope. It is possible that the front marks the boundary between more dense creep deposits onshore and the upper slope and more fluid debris avalanche deposits on the lower slope. Lack of samples makc it impossible to test the validity of this model. The surfaces of the lower slope extensions are quite rough, indicating that they include coarse debris. ( )n the northwest margin, between the Anaga and Teno massifs, larger segments of the sediment front is cut by V-and box-shaped canyons. We speculate that these canyons represent the breakaway surfaces of the channeled debris flows on the northwest lower insular slopes. Erosion by these Hows of the debris avalanche deposits seaward of the front has led to the creation of channels with reliefs of as much as $500 \mathrm{~m}$. We propose that the failure of this sediment front was due to its rapid massive build up with groundwater seeps playing a significant in its failure. On the northwest slope the failures (debris avalanches and/or creep and debris flows) retain their morphology, whereas those on the southeast lower slope are partially buried by postfailure volcanics/detritus. Such burial may explain the absence of postdebris avalanche failure structures on this slope. The only slope failure deposit masked off the northwest slope is on the channel near Anaga massif. Masking at this site is due to a lava flow which originated from a volcano within channel.

Within the dcbris flows on the northwest slope we can rec ognize step-like features which represent secondary flows and longitudinal ridges formed either by compression created by differential movement of the flows or scour. No such structures were identified in the debris flows in the vicinity of Güimar Valley on the southeast slope. The depocenter at the distal ends of the debris flows on the northwest slope is a massive apron consisting of coalescing fans. The fans form two massive lobes with the one on the west extending about $15 \mathrm{~km}$ beyond the rest of the apron. Off the southeast slope these fans have been modified by southerly flowing North $\Lambda$ tlantic Deep Water creating a massive sediment drift of northeast trending ridges and northeast trending lows and overbank deposits southeast of the lows.

Scattered through the surface of the fans off the northwest slope are numerous massive exotic blocks. We infer that the blocks were deposited during the formation of the valleys on land. At present, we also are unable to the determine the mechanics responsible for their transport, but they probably glided along the surface of the flow to their present positions. Such surface gliding was made possible by the high-pressure water in the debris avalanche which acted as a lubricant.

In contrast to the failures off Orotova, Icod, and Güimar, which are indirectly related to failures on land, those off Las Bandas del Sur volcanic fan are a consequence of the failure of the $1700 \mathrm{~m}$ high front of this depocenter and the sediments seaward of the front. Possibly, movements along the fault separating ('jran Canaria and 'lenerife may have enhanced these and other failures on the southeast slope. The swell-valley topography in this region is the result of the superposition of two debris flows with the valley being along the crests of the lower flow. The younger, acoustically transparent upper debris flows extend to the base of the insular slope where they grade into fans.

\section{Conclusions}

The bathymetric and geophysical data recorded during the present investigation coupled with previous investigations, both onshore and offshore, lead us to the following conclusions:

1. Both the northwest and southeast sides and insular slopes of Tenerife are scarred by catastrophic failures. On land the failures occurred at 0.7 to $0.6 \mathrm{Ma}$, which led to the formation of the south draining Güimar Valley on the south coast, and at $0.4-0.3$ and $0.2 \mathrm{Ma}$, which led to the north draining Anaga and Icod de Los Vinos on the north coast. Slope failure deposits associated with these valleys are in the form of avalanche debris and/or creep. Gravity-driven glide blocks associated with these avalanches and/or creep include the $10 \mathrm{~km}$ long, $5 \mathrm{~km}$ wide, and $1 \mathrm{~km}$ thick Tigaiga massif between the Anaga and Icod Valleys.

2. Structures onshore and offshore are separated by scarps hundreds of meters high that represent the front of the debris avalanches and/or creep on land. Extending seaward from these fronts are lobes of more fluid debris avalanches and/or creep. Possibly, the front forms the contact of dense creep deposit onshore and upper slope and more fluid debris avalanche on the lower slope. Off the Las Bandas del Sur volcanic fan the slope is the front of this fan. It is the failure of these fronts which led to the formation of the debris flows incised on debris avalanches and/or creep deposits on the lower slope. The swell-valley topography of Las Banda Del Sur is the result of the superposition of two debris flows with the valley being along the exposed crests of the lower flow.

3. The sediment failures on the southeast insular slope have been modified by postfailure volcanism and sedimentation. The failures on the northwest slope are more pristine. Here the flows are only modified near the Anaga massif where a lava flow from a volcano in the debris channel has partially buried the flow.

4. The debris flows changed downslope into turbidity currents. Deposition by these currents led to the construction of a series of overlapping fans. The acoustic stratigraphy of the fans suggests that slope failures on the scdiment front on the northwest slope occur at various times and places along the front. Off the southeast slope the fan deposits along the contact between this slope and northwest slope of Gran Canaria are being reworked by the southerly flowing North Atlantic Deep Water.

5. On the surface of the fans off the northwest slope is an extensive field of exotic blocks. The blocks may have been transported to their site by gliding along the lubricated surface of the avalanche debris. They probably diverted the turbidity currents created by the debris flows triggered by the collapse of the debris avalanche front on the upper slope.

Acknowledgments. Funding by European Union science program made this geologic investigation of the insular slopes of Tenerife possible. Additional funds provided by Woods Hole Oceanographic Institution allowed for completion of drafting and reproduction of the illustration. We wish to thank Captain J. L. Martinez and the officers and crew of the R/V Hesperides for their cooperation during the cruise. We also are indebted to M. A. Becares, R. Gomez, and J. Molinero of the Instituto Español de Oceanografia, who were in charge of the acquisition system during the cruise and were responsible for the postcruise processing of the data. Maria José Blanco from the Instituto Geográfico Nacional (IGN) provided us with topographic and geodesy information for the GPS base stations and magnetic data from the IGN Observatory which allowed us to apply diurnal corrections to the magnetic data recorded during the cruise. The Instituto Hidrográfico de la Armada, Geotecnica y Cimientos S.A. and the Ministerio de Obras Publicas, Transportes and Medio Ambiente provided us with unpublished geologic data from the region which were of considerable aid in reconstructing the geologic processes that have created the morphology of the northwest and southeast slopes of Tenerife. The illustrations were drafted by A. Martincz. Comments and suggestions by Bill Schwab, Debbie Smith, V. Araña, J. M. Navarro Latorre, S. T. Bolmer, S. R. Gegg, and Emelie E. Hooft were helpful in the writing of this manuscript. Contribution 9470 of the Woods Hole Oceanographic Institution. 


\section{References}

Ancochea, E., J.-M. Fúster, E. Ibarrola, A. Cendrero, J. Coello, F. Hernan, J.-M. Cantagrel, and C. Jamond, Volcanic evolution of the island of Tenerife (Canary Islands) in the light of new K-Ar data, J. Volcanol. Geotherm. Res., 44, 231-249, 1990.

Bellido, F., J. A. Gómez, S. A. Araña, J. Coello, P. A. Hernandez, and L. A. Cueto, Puerto de la Cruz, scale 1:25,000, Mapa geol. Esp., 1103, 90 pp., 1988.

Booth, B., The Granadilla pumice flow deposit of southern Tenerife, Proc. Geol. Assoc., 84, 353-369, 1973.

Bosshard, E., and D. J. MacFarlane, Crustal structure of the western Canary Islands from seismic refraction and gravity data, J. Geophys. Res., 75, 4901-4918, 1970.

Bravo, T., Aportación al estudio geomorfológico y geológico de la costa de la fosa tectónica del Valle de la Orotava, Bol. R. Soc. Esp. Hist. Nat. Secc. Geol., 50, 7-34, 1952.

Bravo, T., El circo de las Cañadas y sus dependencias, Bol. R. Soc. Esp. Hist. Nat. Secc. Geol., 60, 93-108, 1962.

Bryan, S., Bandas Del Sur pyroclastics, southern Tenerife, in A Field Guide to the Central Volcanic Complex of Tenerife (Canary Islands), edited by J. Martí and J. Mitjavila, pp. 39-46, Serv. de Publ. Excmo Cabildo Insular de Lanzarete, Lanzarote, Canary Islands, Spain, 1995.

Bugge, T., R. H. Belderson, and N. H. Kenyon, The Storegga Slide, Philos. Trans. R. Soc. London, Ser. A, 325, 357-388, 1988.

Carracedo, J. C., The Canary Islands: An example of structural control on the growth of large oceanic-island volcanoes, J. Volcanol. Geotherm. Res., 60, 225-241, 1994.

Coello, J., Las series volcánicas en subsuelos de Tenerife, Estud. Geol. Madrid, 29, 491-512, 1973.

Coulbourn, W. T., J. F. Campbell, and R. Moberly, Hawaiian submarine terranes: Canyons and Quaternary history evaluated by seismic reflection profiling, Mar. Geol., 17, 215-234, 1974.

Dash, B. P., and E. Bosshard, Seismic and gravity investigations around the western Canary Islands, Earth Planet. Sci. Lett., 7, 169 177, 1969.

Dott, R. H., Jr., Dynamics of subaqueous gravity depositional processes, Am. Assoc. Pet. Geol. Bull., 47, 104-128, 1963.

Friedmann, S. J., Rock-avalanche elements of the Shadow Valley Basin, eastern Mojave Desert, California: Processes and problems, $J$. Sediment. Res., in press, 1997.

Holcomb, R. T., and R. C. Searle, Large landslides from oceanic volcanoes, Mar. Geotechnol., 10, 19-32, 1991.

Jacobi, R. D., and D. E. Hayes, Northwest African continental rise: effects of near-bottom processes inferred from high-resolution seismic data, in Geologic Evolution of Atlantic Continental Rises, edited by C. W. Poag and P. C. de Graciansky, pp. 293-326, Van Nostrand Reinhold, New York, 1992.

Laronne, J. B., and I. Reid, Very high rates of bedload sediment transport by ephemeral desert rivers, Nature, 366, 148-150, 1993.

Lee, H. J., W. C. Schwab, and D. C. Twichell, Submarine landslides: an introduction, in Submarine Landslides: Selected Studies in the U.S. Exclusive Economic Zone, edited by W. C. Schwab, H. J. Lee, and D. C. Twichell, U.S. Geol. Surv. Bull., 2002, 1-13, 1993.

Lénat, J.-F., P. Bachèlery, A. Bonneville, A. Galdeano, P. Labazuy, D. Rousset, and P. Vincent, Structure and morphology of the submarine flank of an active basaltic volcano: Piton de la Fournaise (Réunion Island, Indian Ocean), Oceanol. Acta, Vol. Spéc., 10, 211223, 1990.

Lipman, P. W., W. R. Normark, J. G. Moore, J. B. Wilson, and C. E. Gutmacher, The giant Alika debris slide, Mauna Loa, Hawaii, $J$. Geophys. Res., 93, 4279-4299, 1988.

Luongo, G., E. Cubellis, F. Obrizzo, and S. M. Petrazzuoli, A physical model for the origin of volcanism of the Tyrrhenian margin: The case of the Neapolitan area, J. Volcanol. Geotherm. Res., 48, 173$185,1991$.

MacFarlane, D. J., and W. I. Ridley, An interpretation of gravity data from Tenerife, Canary Islands, Earth Planet. Sci. Lett., 4, 481-486, 1968.

Martí, J., J. Mitjavila, and V. Araña, Stratigraphy, structure and geochronology of the Las Cañadas Caldera (Tenerife, Canary Islands), Geol. Mag., 131, 715-727, 1994.

Martí, J., J. M. Mitjavila, and V. Araña, The Las Cañadas edifice and caldera, in A Field Guide to the Central Volcanic Complex of Tenerife (Canary Islands), Ser. Casa Valcones, vol. 4, edited by J. Martí and J. Mitjavila, pp. 19-38, Serv. de Publ. Excmo, Cabildo Insular de Lanzarote, Lanzarote, Canary Islands, Spain, 1995.
Masson, D. G., Catastrophic collapse of the volcanic island of Hierro $15 \mathrm{Ka}$ ago, and the history of landslides, Geology, 24, 231-234, 1996.

Mezcua, R., J., J. Gálan G., J. J. Rueda N., J. M. Martínez S., and E. Buforn P., Seismotcctonica de las Islas Canarias, estudio del terremoto del 9 de Mayo de 1989 y su serie de replicas, Inst. Geogr. Nac. Publ. Téc., 23, 24 pp., 1990.

Moore, J. G., and R. K. Mark, Morphology of the island of Hawaii, GSA Today, 2, 257-259, 262, 1992.

Moore, J. G., D. A. Clague, R. T. Holcomb, P. W. Lipman, W. R. Normark, and M. E. Terresan, Prodigious submarine landslides on the Hawaiian Ridge, J. Geophys. Res., 94, 17,465-17,484, 1989.

Moore, J. G., W. R. Normark, and R. T. Holcomb, Giant Hawaiian landslides, Annu. Rev. Earth Planet. Sci., 22, 119-144, 1994.

Nardin, T. R., F. J. Hcin, D. S. Gorsline, and B. D. Edwards, A review of mass movements processes, sediment and acoustic characteristics, and contrasts in slope and base-of-slope systems versus canyon-fanbasin floor systems, in Geology of Continental Slopes, edited by L. J. Doyle and O. H. Pilkey, Spec. Publ. Soc. Econ. Paleontol. Mineral., 27, 61-73, 1979.

Navarro Latorre, J. M., and J. Cocllo, Depressions originated by landslide processes in Tenerife, in ESF Meeting on Canarian Volcanism, pp. 150-152, Eur. Sci. Found., Strasbourg, France, 1989a.

Navarro Latorre, J. M., and J. Coello, Depressiones formadas por deslizamiento gravitacional en Tenerife, paper presented at ESF Meeting on Canarian Volcanism, Eur. Sci. Found., Lanzarote, Canary Island, Spain, 1989 b.

Normark, W. R., J. G. Moore, and M. E. Torresan, Giant-volcanorelated landslides and the development of the Hawaiian Islands, in Submarine Landslides: Selected Studies in the U.S. Exclusive Economic Zone, edited by W. C. Schwab, H. J. Lee, and D. C. Twichell, U.S. Geol. Surv. Bull., 2002, 184-196, 1993.

ODP Leg 157 Shipboard Scientific Party, 1995, Gran Canaria volcanic apron and Madeira Abyssal Plain drilled, Eos Trans. $A G U, 76,393$, $395,1995$.

Palacios, D., The origin of certain wide valleys in the Canary Islands, Geomorphology, 9, 1-18, 1994.

Prior, D. B., B. D. Bornhold, J. M. Coleman, and W. R. Bryan, Morphology of a submarinc slide, Kitimat Arm, British Columbia, Geology, 10, 588-592, 1982.

Reid, I., M. Powell, J. B. Laronne, and C. Garcia, Flash floods in desert rivers: Studying the unexpected, Eos, 75, 452, 1994.

Staudigel, H., and H.-U. Schminckc, The Pliocene Seamount Series of La Palma/Canary Islands, J. Geophys. Res., 89, 11,195-11,215, 1984.

Stoopes, G. R., and M. F. Shcridan, Giant debris avalanches from the Colima volcanic complex, Mexico (implications for long-runout landslides (>100 km) and hazard assessment, Geology, 20, 299-302, 1992.

Varnes, D. J., Lanslide types and processes, Publ. 544, pp. 20-47, U.S. Natl. Res. Counc., Washington, D. C., 1958.

Voight, T., H. Glicken, R. J. Janda, and P. M. Douglass, The 1980 eruptions of Mount St. Helens, Washington, U.S. Geol. Surv. Prof. Pap., 1250, 347-377, 1981.

Watts, A. B., and D. G. Masson, A giant landslide in the north flank of Tenerife, Canary Islands, J. Geophys. Res., 100, 24,487-24,498, 1995.

Williams, R. S., and D. Fernandopullé, Geological analysis of aerial thermography of the Canary Islands, Proc. Int. Symp. Remote Sens. Environ., 8th(II), 1159-1193, 1972.

Wolfe, C. J., M. K. McNutt, and R. S. Detrich, The archipelagic apron: Seismic stratigraphy and implications for volcanic growth, mass wasting and crustal underplatting, J. Geophys. Res., 99, 13,59113,608, 1994.

J. Acosta, P. Herranz, A. Muñoz, C. Palomo, and J. L. Sanz, Instituto Español de Oceanografia, Corazon de Maria, 8, Primer Piso, 28002 Madrid, Spain. (e-mail: juan.acosta@md.ieo.es; araceli.mrecio@md.ieo.es; carlos.palomo@md.ieo.es)

J. Fscartin, Department of Geological Sciences, University of Durham, South Road, Durham DH1 3LE, England. (c-mail: javier.escartin@durham.ac.uk)

E. Uchupi, Geology and Geophysics Department, Woods Hole Oceanographic Institution, Woods Hole, MA 02543. (e-mail: euchupi@whoi.edu)

(Received July 24, 1996; revised April 1, 1997; accepted April 24, 1997.) 